\title{
Arcydzieła z ciasta. Toruńskie pierniki w zbiorach muzealnych w Polsce i na świecie
}

„Odkryć, ponumerować, skatalogować, i schować w szafach muzealnych — oto namiętność badaczy przeszłości. No bo i cóż innego można zrobić z mumją egipską lub narzędziami tortur średniowiecznych. Są to rzeczy umarłe, do których stosunek współczesnego życia przejawia się tylko w zainteresowaniach, mniej lub więcej, ściśle naukowych. Istnieją jednak rzeczy przedwcześnie pogrzebane w muzeach, mające prawo do życia, zapadłe w ciężki letarg z którego warto je obudzić. W takim właśnie letargu pogrążony jest Piernik Toruński” — pisał w 1935 r. Witold Ulanowski [1935: 437] ${ }^{1}$. Obserwacja artysty słynącego jako „malarz pierników”2 świadczy między innymi o charakterystycznej dla okresu międzywojennego fascynacji słynnymi toruńskimi wypiekami dekoracyjnymi. Wiązała się ona z zachwytem nad kunsztem i urodą kształtów, zaciekawieniem funkcją tego typu pieczywa, w gruncie rzeczy trudno jadalnego, ale o wysokich walorach estetycznych, wreszcie z nostalgią wiążącą się z łączeniem pier-

\footnotetext{
${ }^{1}$ Artykuł jest ilustrowany zdjęciami polichromowanych i złoconych toruńskich pierników figuralnych. Witold Ulanowski (1893-1980) — łódzki artysta, malarz i rzeźbiarz. Zob.: http://www.piernikarka.pl/index.php/2020/03/21/wiersz-o-malarzu-piernikow/, data odczytu: 15.07.2020.

${ }^{2}$ Określenia tego użył poeta Konstanty Ildefons Gałczyński (1905-1953) w wierszu pt.: Pierniki toruńskie.Zob.:http://www.piernikarka.pl/index.php/2020/03/21/wiersz-o-malarzu-piernikow/, data odczytu: 15.07.2020.
} 
ników z okresem staropolskim, traktującym je jako elementy przenoszące pamięć o dawnym wybitnym rzemiośle piernikarskim z Torunia.

Toruńskie pierniki figuralne wraz $\mathrm{z}$ formami piernikarskimi w kontekście muzealnym zaklasyfikować można do grupy artefaktów kultury kulinarnej ${ }^{3}$ i jako takie traktować jako źródło poznawcze do badań nad dziejami kultury materialnej i niematerialnej, szczególnie w kontekście lokalnej społeczności jaką tworzą mieszkańcy Torunia. Tradycje te jednak wychodzą poza lokalność, wpisując się w kontekst międzynarodowy.
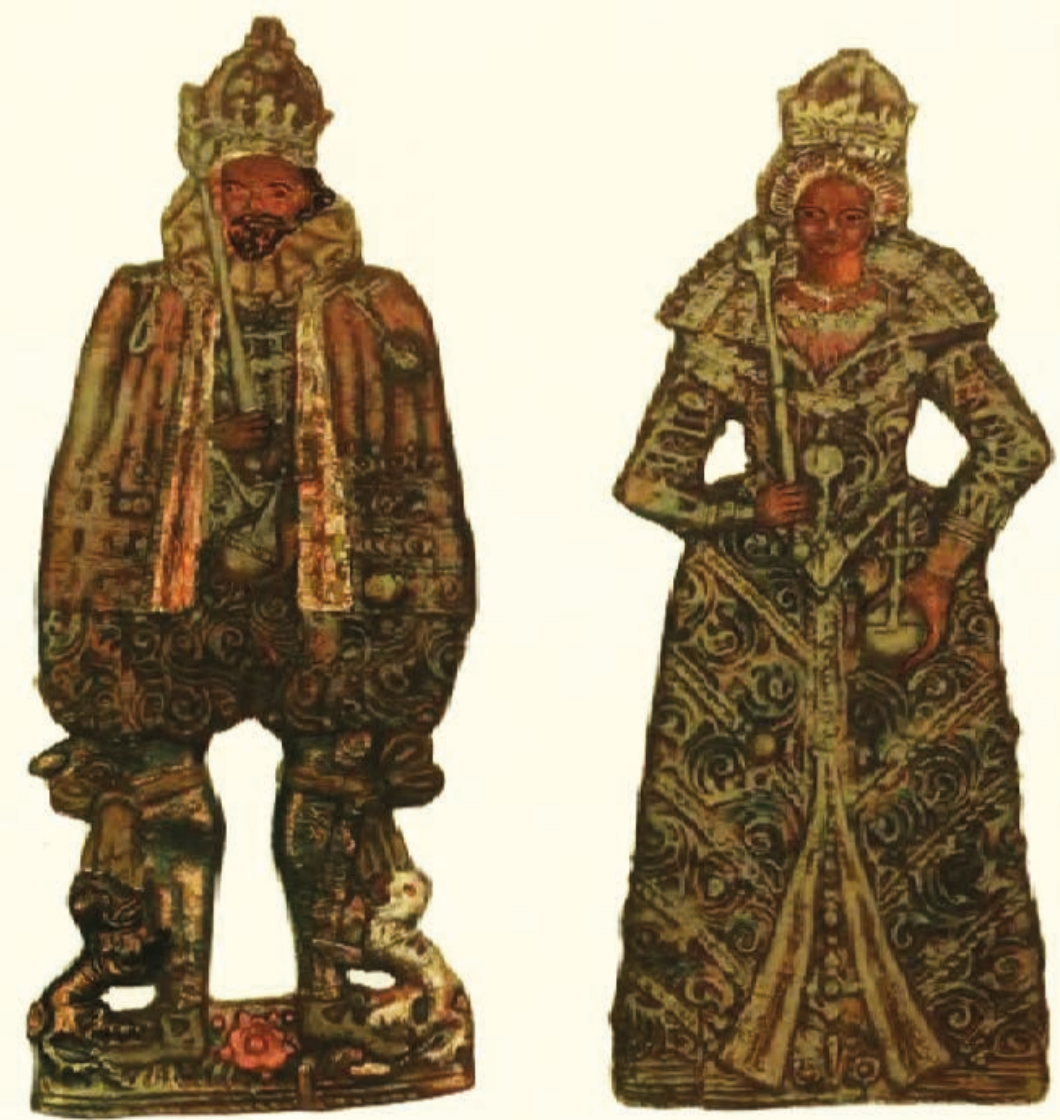

Il. 1. Pierniki królewskie Zygmunt III Waza i Konstancja, polichromowane, złocone, ilustracja artykułu Witolda Ulanowskiego pt. „Ciasto św. Priski” w Arkady 1935 rok, r. 1, nr 8, s.436, źródło: KujawskoPomorska Biblioteka Cyfrowa, https://kpbc.umk.pl/publication/17429

\footnotetext{
${ }^{3}$ Zarówno jako produkty spożywcze (pierniki), jak i przedmiotów służących do ich wyrobu (formy piernikarskie) zob.: Krzysztof M. Kowalski [1993: 44].
} 
Wzrost zainteresowania piernikami figuralnymi związany był niewątpliwie z pracami badawczymi Stanisława Dąbrowskiego [1926]. W 1926 r. ukazała się jego publikacja będąca kamieniem milowym w opracowaniu dziejów piernikarstwa w Toruniu. Było to praktycznie pierwsze monograficzne, napisane w języku polskim, ujęcie problematyki toruńskich tradycji związanych z wypiekiem pierników. Artykułowi towarzyszył katalog form piernikarskich uzupełniony o ilustracje przedstawiające zdjęcia toruńskich wypieków figuralnych. Zostały one ukształtowane za pomocą drewnianych form, znajdujących się wówczas w kolekcjach fabryk Gustawa Weesego i Herrmanna Thomasa ${ }^{4}$. Badania Dąbrowskiego nad drewnianymi formami piernikarskimi, opublikowane w „Roczniku Toruńskim”, ale również w czasopismach w formie krótszych artykułów o charakterze popularyzatorskim, przywróciły pamięć o roli toruńskiego piernika figuralnego w kulturze polskiej [Dąbrowski 1931, 1935]. Nie bez znaczenia był fakt, że w roku publikacji, minęło już 6 lat od powrotu Torunia do Macierzy. W owym czasie poszukiwano oraz podkreślano związki miasta z Polską. Piernik toruński stał się symbolem polskości i polskiej tradycji, kunsztu rzemiosła piernikarskiego, artystycznego oraz snycerstwa. Jako taki, szczególnie stał się atrakcyjny dla zbiorów muzealnych. Formy z XVII i XVIII w. - przedstawiające np. świętych, alegorie, wizerunki polskich władców, - występowały w pojedynczych egzemplarzach, przechowywanych wówczas w fabrykach i stanowiących własność fabrykantów ${ }^{5}$. Muzea nie mogły więc nabywać ich do zbiorów. Zatem o wiele łatwiejsze stało się kolekcjonowanie samych wypieków - ozdobnych pierników figuralnych.

Pierwsze tego typu nabytki trafiły do Muzeum Etnograficznego w Krakowie już w 1925 r. Kolejne zasiliły zbiory tzw. „drugiego” Muzeum Polskiego w Rapperswilu. Prezentowane były także na Wystawie Światowej w Nowym Jorku, stanowiąc przykład wybitnego polskiego rzemiosła artystycznego. Do dzisiaj w placówkach muzealnych odnaleźć możemy kilkadziesiąt toruńskich pierników figuralnych, w dużej mierze wypieczonych w okresie międzywojennym. Część z nich uległa prawdopodobnie zniszczeniu podczas

\footnotetext{
${ }^{4}$ Więcej o kolekcji i inwentarzu form oraz badaniach prowadzonych przez S. Dąbrowskiego i jego biografii: Jędrzejewska [2018: 207-220]. Dąbrowski w katalogu wzmiankował jeszcze formy z fabryki Jana Ruchniewicza oraz muzeów miejskich w Toruniu i Grudziądzu. Natomiast artykuł był ilustrowany jedynie piernikami z fabryk Gustawa Weese i Herrmanna Thomasa.

${ }^{5}$ O kolekcji form Gustawa Weese wspomina Edward Chwalewik w opracowaniu: Zbiory polskie: „Weese G. Bogaty zbiór form piernikowych oraz archiwum cechu piekarskiego”. [Chwalewik 1927, 256].
} 
działań wojennych ${ }^{6}$. Dotychczasowe badania koncentrowały się głównie na formach piernikarskich. Zachowane w zbiorach pierniki nie zostały szczegółowiej opracowane i opisane, poza nielicznymi wzmiankami. Niniejszy artykuł stanowi uzupełnienie stanu wiedzy?

\section{Produkt spożywczy jako muzealium. Problematyka przechowywania i prezentowania pieczywa obrzędowego w muzeach}

Przechowywanie pierników w zbiorach muzealnych stanowi wyzwanie dla zespołów pracowników opiekujących się wpisanymi do inwentarzy muzealiami. Dotyczy to generalnie produktów żywnościowych, które należą bodajże do najmniej chętnie gromadzonych zbiorów ${ }^{8}$. Największe doświadczenie w pracy nad tego typu obiektami mają muzealnicy pracujący w muzeach etnograficznych. Ich wiedza oraz praktyczne umiejętności wynikają z długiej tradycji opieki nad dziedzictwem materialnym związanym z żywnością, produktami spożywczymi łączonymi z obrzędami i zwyczajami. W zbiorach polskich są to m.in. pisanki, pieczywo obrzędowe (korowaje, kurki z ciasta, pierniki odpustowe), opłatki, wyroby cukiernicze i wyroby z sera. Zaskakująco skromnie na tle popularności tych zbiorów prezentuje się literatura fachowa dotycząca sposobów opieki nad tego typu zabytkami. Nie opracowano dotąd także monograficznego ujęcia tej problematyki. Praktyka muzealna wskazuje na istotną rolę doświadczenia i przekazywania informacji przez kolejne pokolenia pracowników danej instytucji. Doświadczenie w zakresie opieki nad obiektami artystycznymi zbudowanymi z elementów jadalnych i efemerycznych mają także muzea sztuki nowoczesnej ${ }^{9}$.

Przedmiotowe toruńskie pierniki, podobnie jak inne pierniki, zaliczamy do grupy obiektów o charakterze pieczywa odpustowego oraz obrzędowego.

\footnotetext{
${ }^{6}$ Tak mogło być w przypadku pierników przechowywanych w zbiorach muzeum miejskiego w Toruniu. Pierniki występują w inwentarzu, natomiast po II wojnie światowej już ich nie odnaleziono.

${ }^{7}$ Autorka przeprowadziła badania w ramach przygotowywanej rozprawy doktorskiej pt.: Toruńskie kolekcje form piernikarskich pod kierunkiem dr hab. Tomasza F. de Rosseta, prof. UMK, na Wydziale Sztuk Pięknych UMK w Toruniu. Prowadzi także blog „Piernikarka”, na którym popularyzuje wiedzę o piernikarstwie. http://www.piernikarka.pl/index.php/2019/07/18/ sladami-torunskich-piernikow/_data odczytu: 03.06.2020.

${ }^{8} \mathrm{Na}$ temat m.in.: Anne Ewbank [2019]; Conservator Bronwen [2013]; Megan Harvey, Cerys Davidson, Coralie O’Hara [2016].

${ }^{9} \mathrm{O}$ konserwacji obiektów spożywczych w kontekście sztuki współczesnej m.in.: Julie Gilman, Claire Van Damme, Bruno Demeulenaer and Frank Devlieghere [2011]; Alexandra Jeberien und Christian Lindhorst [2003]; Jennifer Levy [2008: 38]. W Polsce wywiązała się dyskusja na temat konserwacji dzieł Władysława Hasiora z cyklu: Chleb polski.
} 
Głównymi zagrożeniami dla tego typu zabytków są między innymi: kruchość materiału, a tym samych narażenie na uszkodzenia mechaniczne (przy przenoszeniu, eksponowaniu i transporcie obiektów), przemijanie walorów estetycznych zabytku (m.in. kruszenie lukru, uszkodzenia powierzchni, która matowieje, zmniejszenie objętości, zmiany kolorystyczne, szarzenie), utrata właściwości konsumpcyjnych, a przede wszystkim szczególne narażenie na działanie pleśni (pojawiających się wraz ze zmianami wilgotności i temperatury) czy insektów żerujących na cieście.

Praca z tego typem wrażliwym obiektem jest wyzwaniem dla zarówno kustoszy odpowiedzialnych za zbiory, jak i konserwatorów muzealnych. W czasie konsultacji i kwerend z pracownikami muzeów ${ }^{10}$ wskazywano na wypracowane procedury związane z opieką nad pieczywem piernikowym. Kluczowe są regularne, dość częste kontrole i przeglądy w magazynie, w którym przechowuje się obiekty. Pierniki zamykane są zwykle w wyściełanych tekturowych pudełkach z przykryciem. Opakowania są odpowiednio opisane i oznaczone numerami inwentarzowymi i zdjęciami poglądowymi. Warunki w magazynach są uwspólnione dla obiektów w nich przechowywanych. Stosowaną praktyką jest ograniczenie ruchu muzealiów, ponieważ właśnie często transport związany z wypożyczeniami powoduje uszkodzenia (pękanie, kruszenie, odłamanie fragmentów). Eksponaty prezentowane na wystawach stałych i czasowych, z reguły wybierane są także pod kątem walorów estetycznych oraz stabilności i zwartości całości.

Do innych działań związanych z konserwacją pieczywa należy zabezpieczenie przed insektami (molami spożywczymi) poprzez środki odstraszające oraz usuwanie skutków wyrządzonych przez owady żerujące

\footnotetext{
${ }^{10}$ Dziękuję za konsultacje prof. Bogumile Roubie z Katedry Konserwacji — Restauracji Malarstwa i Rzeźby Polichromowanej, prof. Monice Jadzińskiej z Wydziału Konserwacji i Restauracji Dzieł Sztuki Akademii Sztuk Pięknych w Warszawie, a także kolegom i koleżankom z muzeum: Hannie Łopatyńskiej, Ewie Martin-Sobeckiej i Grażynie Szelągowskiej z Muzeum Etnograficznego im. Marii Znamierowskiej-Prüfferowej w Toruniu, Karolinie Pachli-Wojciechowskiej oraz Działowi Konserwacji z Muzeum Etnograficznego im. Seweryna Udzieli w Krakowie, dr inż. Annie Grześkowiak-Przyweckiej i Paulinie Kryg z Narodowego Muzeum Rolnictwa i Przemysłu Rolno-Spożywczego w Szreniawie, Alicji Mironiuk-Nikolskiej oraz Działowi Konserwacji Państwowego Muzeum Etnograficznego w Warszawie. Autorka w czasie swojej pracy zawodowej w Dziale Historii Toruńskiego Piernikarstwa Muzeum Toruńskiego Piernika - oddziale Muzeum Okręgowego w Toruniu, współpracowała nad gromadzonymi piernikami toruńskimi z pracownikami Działu Konserwacji Aliną Targowską, Katarzyną Łukawską, Krystyną Noworytą-Przystał i Ewą Brewką. Gromadzone wypieki nie były wpisywane do inwentarza, natomiast po zaatakowaniu przez insekty były poddawane procesowi wymrażania. Krzysztof Lewandowski - obecny pracownik Działu dodaje, że pierniki po wymrożeniu ponownie podpiekano. Zdarzało się też, że ubytki uzupełniano także ciastem.
} 
na zabytkach. Niekiedy pieczywo zainfekowane przez larwy poddaje się zabiegom wytrucia poprzez zagazowanie, dezynsekcję lub wymrażanie. Pieczywo często ma otworki - są to dawne ślady po zaatakowaniu przez owady. Ubytki czasem wypełnione są pianką poliuretanową. Pierniki bywają także zaatakowane przez pleśnie. Konserwacja tego typu obiektów jest trudna i stanowi wyzwanie, tym bardziej, że jak już wspomniano brakuje opracowań związanych z tą tematyką.

Pierniki toruńskie wpisywane do inwentarzy w latach 20. a potem 50. i 60. XX w., dzisiaj po blisko 100 latach są w różnym stopniu zachowane. $Z$ biegiem czasu te wrażliwe zabytki ulegały destrukcji, nawet niezależnie od opisanych wyżej czynników zewnętrznych. Procedura wykreślenia muzealiów z inwentarzy muzealnych jest skomplikowana, stąd obecnie muzea w Polsce wypracowały praktykę niewpisywania doń obiektów zrobionych z nietrwałych materiałów o charakterze spożywczym. Ewidencjonuje się je w tzw. inwentarzach pomocniczych, często wykonując dokumentację fotograficzną, w miarę możliwości uzupełniając zbiory o kolejne nabytki wytwarzane przez te same pracownie piernikarskie (o ile jeszcze funkcjonują).

Prezentowanie eksponatów zrobionych z materiałów spożywczych jest wyzwaniem. W muzeach zabronione jest wnoszenie i konsumowanie produktów żywnościowych, co określają regulaminy zwiedzania [Fic-Lazo 2015: 32]. Wynika to z troski o zabezpieczenie zbiorów, w szczególności przed insektami. Niemniej w kolekcjach muzealnych znajdujemy obiekty, które wcześniej miały przeznaczenie konsumpcyjne. Zabytki powstałe z materiałów spożywczych i organicznych, są podwójnym wyzwaniem dla opiekunów kolekcji. Z jednej strony mogą stanowić zagrożenie, ze względu na materiał z którego powstały, z drugiej jako wpisane do muzealnego inwentarza stają się dobrem kultury, prawnie chronionym. To swoiste napięcie między pierwotną, często częściowo, konsumpcyjną funkcją a jego nabytą rolą muzealium nie tylko nie umniejsza jego atrakcyjności, ale powoduje wręcz wzrost zainteresowania. Goście muzealni szukając w muzeach autentyczności i oryginalności, zostają zaskoczeni kontaktem z obiektem, który według doświadczenia codzienności powinien ulec szybkiej destrukcji, a w tym przypadku został zachowany. W kontekście rosnącej fali zainteresowań turystyką kulinarnej oraz regionalnym dziedzictwem kulinarnym to muzeum jest gwarantem autentyczności prezentowanych zbiorów [Woźniczko, Orłowski 2017: 186]. 


\section{Kolekcje toruńskich pierników figuralnych. Prezentacja i charakterystyka}

Pierniki figuralne, inaczej zwane piernikami ozdobnymi lub historycznymi, kształtowano w Toruniu za pomocą drewnianych a z czasem także metalowych form ${ }^{11}$. Pełniły funkcje estetyczne, dekoracyjne, bywały malowane, złocone. Efemeryczny charakter wypieków sprawił, że do naszych czasów dotrwało niewiele artefaktów zrobionych z ciasta. O tym jak wyglądały toruńskie pierniki w XVII, XVIII i XIX w. wiemy właściwie dzięki zachowanym w zbiorach muzealnych formom piernikarskim. Pierwsze fotografie przedstawiające wypieki figuralne z Grodu Kopernika pochodzą z początku XX w. Poprzez określenie „toruńskie pierniki figuralne” rozumieć należy ozdobne wypieki, ukształtowane z ciasta piernikowego za pomocą drewnianych i metalowych form. Zarówno formy, jak i masa piernikarska, pochodzić powinny z fabryk zlokalizowanych w Toruniu. Pieczywo takie wypiekały fabryki Gustawa Weesego, Herrmanna Thomasa, Jana Ruchniewicza ${ }^{12}$. Obecnie toruńskie pierniki figuralne wypiekane są nadal w Fabryce Cukierniczej „Kopernik” SA.

Obserwowany w pierwszym dwudziestoleciu XXI w. wzrost zainteresowania odradzającymi się lokalnymi tradycjami związanymi z piernikami, nie tylko w Toruniu, ale i na Śląsku i w innych regionach oraz rozwój badawczy nad problematyka piernikarstwa w Polsce ${ }^{13}$, dały impuls do poszukiwania w zasobach muzealnych materialnych śladów popularności korzennych wypieków. Wynik kwerendy przyniósł ciekawe spostrzeżenia

\footnotetext{
${ }^{11}$ Płaskorzeźby wykonywano za pomocą reliefu wklęsłego. Wraz z rozwojem przemysłu piernikarskiego, przy produkcji pierników zaczęto stosować formy metalowe. W okresie przejściowym drewniane formy obijano blachą. Obecnie używane są także formy z tworzyw sztucznych. Nadal jednak zamawiane są formy drewniane. Współczesnymi wykonawcami drewnianych klocków piernikarskich są m.in. twórcy ludowi Zygmunt Kędzierski i Danuta Sroka, artyści rzeźbiarze dr Stanisław Kośmiński, rzemieślnicy i snycerze amatorzy Andrzej Pietrzak, Tadeusz Makowski, Beata Pranke-Zdziebło oraz mistrz snycerski z Czech Oldřich Kvapil i jego uczeń Tomasz Karamon.

${ }^{12} \mathrm{~W}$ zbiorach muzealnych nie zachowały się pierniki z polskiej fabryki Jana Ruchniewicza. Wspomina o nich w swoim artykule Stanisław Dąbrowski oraz wzmianki prasowe.

${ }^{13} \mathrm{~W}$ ostatnich latach Anna Rumińska, antropolożka i liderka convivium Slow Food Dolny Śląsk zaproponowała termin „piperatologia” — jako nazwę subdyscypliny wiedzy na temat piernikarstwa i pierników, analogicznie badacze zajmujący się tą dziedziną określani byliby jako piperatolodzy i piperatolożki. Terminologia ta staje się coraz bardziej popularna. Szersze objaśnienie rozumienia terminu, badaczka zawarła w opracowaniu „Antropologia piernika. Compendium piperatologiczne” z 2020 roku. Kompendium można zamówić online. Planowane jest wydanie naukowe. http://slowfooddolnyslask.org/woj-dla-dzieci/artystyczny-warsztat-piernikarski-slow-food-na-726-lecie-dolnoslaskiego-piernikarstwa/data odczytu: 3.06.2020.
} 
dotyczące toruńskich pierników, które znalazły się w zbiorach muzeów w Krakowie, Poznaniu, Łodzi, a nawet w Londynie i Chicago.

\section{Pierniki w zbiorach w Krakowie}

Najwcześniejsze ślady pozyskiwania toruńskich pierników do kolekcji związane jest z obecnym Muzeum Etnograficznym im. Seweryna Udzieli w Krakowie ${ }^{14}$. W artykule pt.: Pierniki toruńskie z 1925 r. czytamy:

Tradycje dawnego przemysłu piernikarskiego, przechowują jeszcze dwie stare firmy w Toruniu: Weesego i Tomasa, które przechowały dotychczas stare formy do wyrabiania pierników z XVII i XVIII w. i dzięki zabiegom p. Stanisława Dąbrowskiego udało się uzyskać do Muzeum etnograficznego w Krakowie na tych dawnych formach wyrobionych kilkadziesiąt pierników. Można tu podziwiać bardzo staranne, prawie artystyczne wykonanie form w drzewie, w których wygniecione pierniki mają podobieństwo płaskorzeźb rżniętych w drzewie lub kamieniu [Udziela 1925: 20].

Artykuł ilustrowany jest czterema piernikami toruńskimi przedstawiającymi pary królewskie: Zygmunta III Wazy z żoną Konstancją oraz Władysława IV Wazy z żoną Cecylią Renatą ${ }^{15}$. W artykule Udzieli wspomniana jest rola wspominanego-Stanisława Dąbrowskiego w pozyskiwaniu pierników do zbiorów. On sam pisał: „Reprodukowane odciski pierników w cieście oraz niektóre inne zostały ofiarowane przez firmy G. Weesego i H. Thomasa Muzeum etnograficznemu na Wawelu w Krakowie i tam się znajdują” [Dąbrowski 1926: 287]. Warto dodać, że fotografie umieszczone w publikacji Dawne pierniki toruńskie z 1926 r. wykonane zostały w zakładzie reprodukcji fototechnicznej Stanisława Welanyka w Krakowie i przedstawiają pierniki pozyskane do krakowskiej kolekcji. Są to jedne z najstarszych fotografii odcisków toruńskich pierników figuralnych ${ }^{16}$.

\footnotetext{
${ }^{14} \mathrm{~W}$ zachowanym w archiwum krakowskiego muzeum fragmencie artykułu Jerzego Dobrzyckiego [1925]: czytamy: „Muzeum Etnograficzne na Wawelu może rok ubiegły zaliczyć do szczęśliwych. Zbiory muzealne poszerzyły się w tym czasie znakomicie [...]. Do ciekawszych okazów należy też kolekcja pierników toruńskich, wypieczonych dla Muzeum przez dwie firmy w Toruniu, w formach z 17 wieku. Pierniki te przedstawiają ówczesnych królów i królowe polskie we wspaniałych strojach, dalej sceny biblijne, postacie świętych, rycerzy itd.”.

${ }^{15} \mathrm{~W}$ podpisie ilustracji pierników nastąpiły błędy. Omyłkowo zidentyfikowano pary. Wizerunki Zygmunta III i Konstancji podpisano jako Władysława IV i Cecylii Renaty. Zob. tamże: s. 21.

${ }^{16}$ Do najstarszych należy piernik przedstawiający Zygmunta III Wazę i podpisany „niemiecki cesarz" jako element germanizacji, Sonntag Zeitung 1904, archiwum Działu Historii Toruńskiego Piernikarstwa Muzeum Okręgowego w Toruniu.
} 


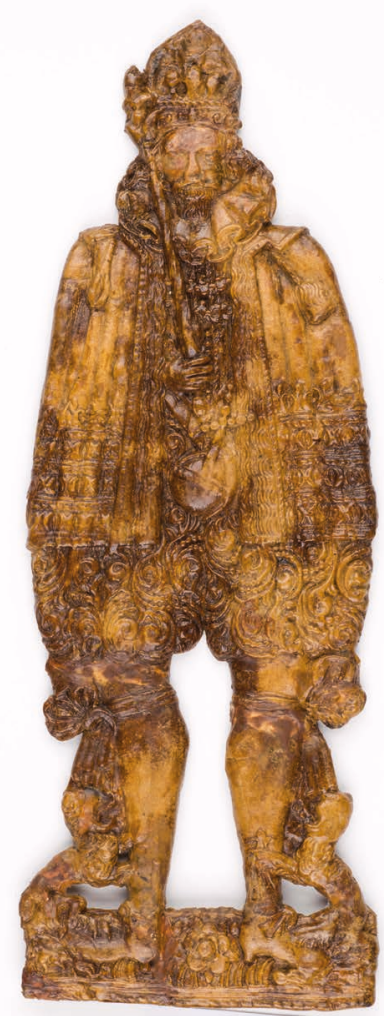

Il. 2. Piernik toruński król Zygmunt III Waza 1925 r., Toruń, firma Gustav Weese, Muzeum Etnograficzne im. Seweryna Udzieli w Krakowie, nr inw. 4501/MEK, (Fot. MEK)

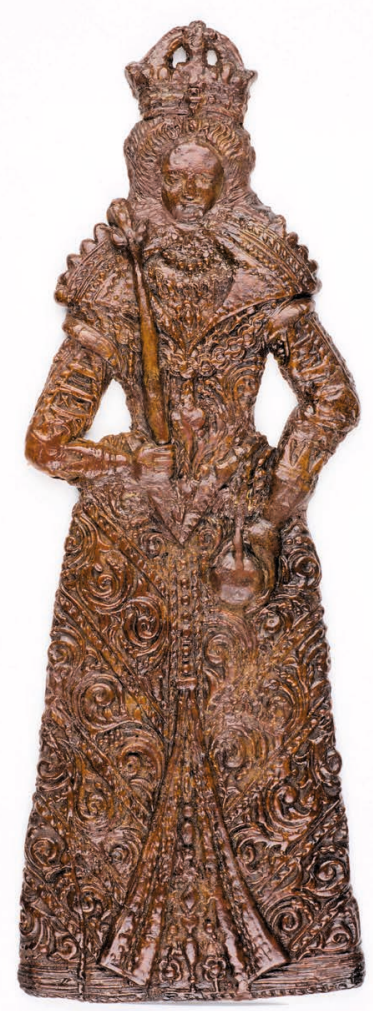

Il. 3. Piernik toruński królowa Konstancja, 1925 r., Toruń, firma Gustav Weese, Muzeum Etnograficzne im. Seweryna Udzieli w Krakowie, nr inw. 4502/MEK, (Fot. MEK)

Przekazane w 1925 r. do Krakowa pierniki, zostały wpisane z do inwentarza w 1928 r.. Pierniki były eksponowane w tzw. „refektarzu” w budynku dawnego seminarium na Wawelu. W artykule z 1927 r. czytamy: „W 3 salach parterowych znajdujemy najpiękniejsze zbiory. W dawnym refektarzu znajdują się przepiękne hafty, stroje, drzeworyty ludowe, rzeźby ludowe [...] oraz ciekawy zbiór pierników toruńskich, wykonanych w XVII w. [...]; wspaniały jest piernik z firmy H. Thomas w Toruniu z roku 1637, przedstawiający królową polską Cecylię Renatę, żonę Władysława IV” Wargowski 1927: 7]. Seweryn Udziela [1927] opublikował także inny artykuł pt.: Pierniki w Polsce, w którym opisywał toruńskie wypieki. Tekst był ilustrowany zdjęciami 26 pierników. 
Obecnie zespół liczy 42 pierniki ${ }^{17} .34$ pochodzą z ok. 1925 r. — z pierwszego przekazu w 1925 r., wpis do inwentarza z 1928 r. Siedem pochodzi ze zbiorów Rapperswilu z ok. 1930 r., wpisane do inwentarza w 1953 r. Jeden został podarowany przez licealistów z Torunia w 1961 r.. Pierniki z kolekcji zostały wypożyczone na wystawę czasową do Torunia w 1954 r. i włączone do katalogu autorstwa Janiny Kruszelnickiej [1956].

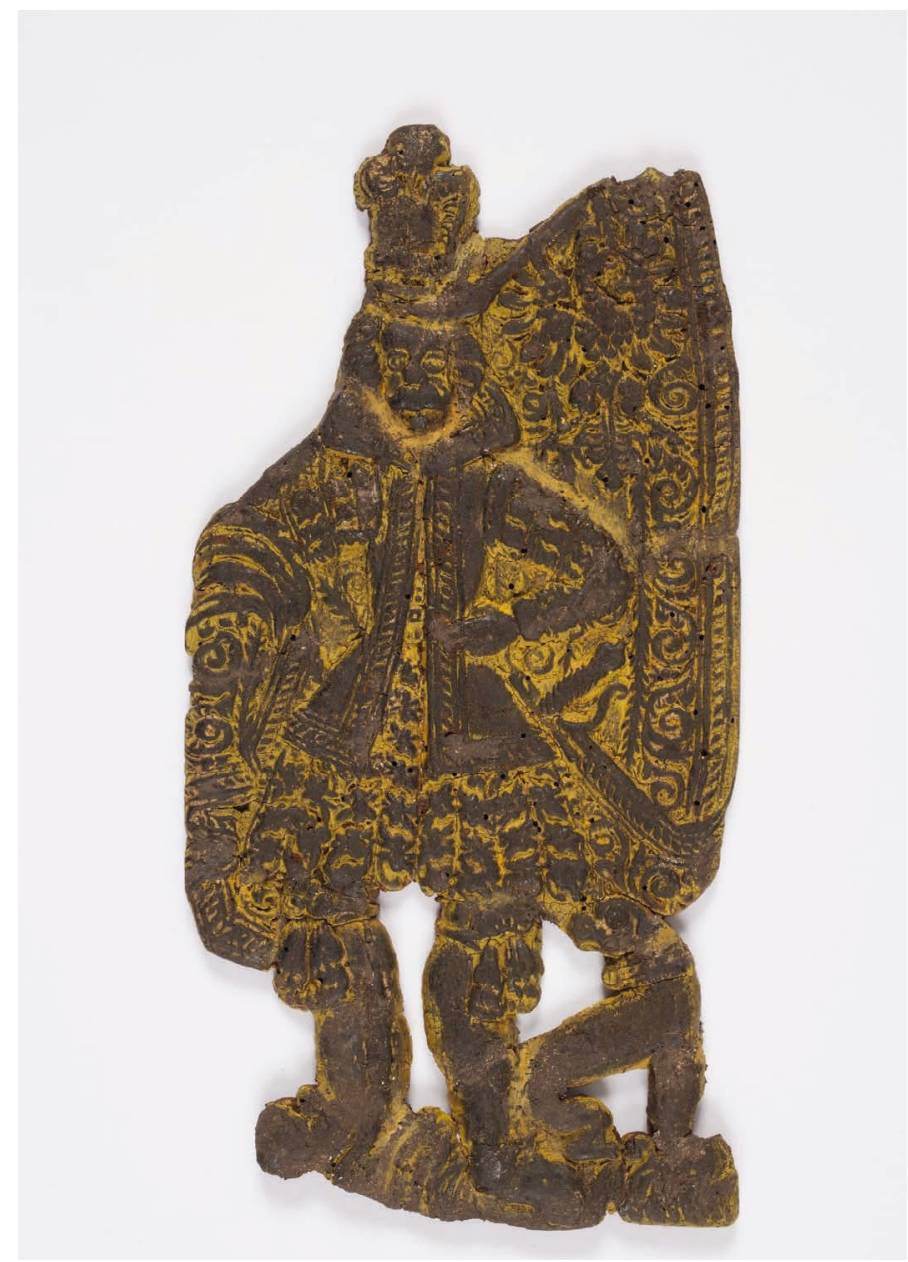

Il. 4. Piernik toruński Chorąży, Toruń, firma Gustav Weese, lata 20-30te XX w., z niezachowanej formy piernikarskiej, przekazane z Muzeum w Rapperswilu, ślady polichromii, Muzeum Etnograficzne im. Seweryna Udzieli w Krakowie, polichromia, nr inw. 15442/MEK, (Fot. MEK)

\footnotetext{
${ }^{17}$ Dziękuję Pani Karolinie Pachli-Wojciechowskiej oraz Panu Janowi Tomaszewskiemu z Muzeum Etnograficznego im. Seweryna Udzieli w Krakowie za konsultacje podczas kwerendy.
} 
Motywami występującymi są: Król Zygmunt III, Królowa Konstancja, Król Władysław IV, Królowa Cecylia Renata, Katarzynka, Trębacz na koniu, Saneczki z trzema gęsiami, Hołd Trzech Króli (2), Archanioł Michał, Alegoria Miłości Chrześcijańskiej (2), Alegoria Roztropności, Popiersie Tadeusza Kościuszki, Święty Jerzy na koniu (2), Dama przy kołowrotku Prządka (2), Kogut niosący na grzbiecie zwierzę grające na dudach, Scena humorystyczna pod drzewem (2), Tambour-major, Dzik, Rękawiczki, Dama (4), Dama jako pasterka, Dama tańcząca, Huzar na koniu (3), Rzeźnik z wołem (2), Jelonek (2), Chorąży, Syrena, Kawaler z fajką, Kawaler z mieczem, Rycerz, Mikołaj Kopernik. Część wizerunków pierników jest zdigitalizowana i udostępniona w repozytorium cyfrowym ${ }^{18}$. Na stronie muzeum rozbudowaną informację posiada toruńska katarzynka ${ }^{19}$.

\section{Pierniki w zbiorach w Muzeum Polskiego w Rapperswilu}

Pierniki toruńskie znajdowały się w tzw. drugim Muzeum - Muzeum Polski Współczesnej 1936-1952 w Rapperswilu. Po jego likwidacji w 1952 r., zbiory zostały wywiezione do Polski i trafiły do Muzeum w Łowiczu i innych muzeów w Polsce ${ }^{20}$. Pierniki te noszą ślady zachowanej polichromii i złoceń. Zostały wyciśnięte w toruńskich klockach piernikarskich na pewno przed 1939 r. Świadczy o tym fakt, że niektóre z form użytych do pierników zaginęły w czasie II wojny światowej. Przetrwały same wypieki. O proweniencji rapperswilskiej wspomina Janina Kruszelnicka [1956: 8] ${ }^{21}$.

\section{Pierniki w zbiorach w Poznaniu}

Muzeum Etnograficzne - oddział Muzeum Narodowego w Poznaniu w swoich zbiorach gromadzi zespół 8 pierników toruńskich o kolejnych

\footnotetext{
${ }^{18} \mathrm{O}$ problematyce korzystania z Internetu wspominam w artykule Narzędzia cyfrowe do badań nad dziejami piernikarstwa (w druku). Odnośnie rozpoznania ikonograficznego poszczególnych pierników, w artykule podano nazwy używane w muzeach. Czasami to samo przedstawienie jest w danych instytucjach inaczej określane. W niniejszym opracowaniu, ze względu na ograniczenia związane z objętością, nie podjęto ujednolicenia przedstawień. Zagadnienie to rozwijam w przygotowywanej rozprawie.

${ }^{19} \mathrm{https} / / /$ etnomuzeum.eu/zbiory/piernik-torunski-katarzynka, data odczytu: 3.06.2020 opracowanie Karolina Pachla-Wojciechowska, z którą miałam przyjemność współpracować przy konsultacji obiektu.

${ }^{20}$ Konsultacje przeprowadzone z Robertem Pawłowskim Kierownikiem Archiwum Muzeum w Rapperswilu. Dokumenty oraz ówczesny inwentarz muzealny znajduje się w Archiwum Akt Nowych w Warszawie.

${ }^{21} \mathrm{~W}$ katalogu badaczka przywołuje zbiory pierników z muzeów w Krakowie, Łodzi i Poznaniu, s. 74-78, s. 84-85.
} 
sygnaturach od E-919 do E-92622. Obiekty wpłynęły do zbiorów na mocy protokołu z 8 maja 1953 r. Na kartach znajduje się informacja: „Ze zbiorów rapperswilskich”. Datowane są na ok. 1930 r. Pierniki przedstawiają: pieczęć majestatyczną króla Władysława IV Wazy, świętego Jerzego, Matkę Bożą z Dzieciątkiem (lub Damę z dzieckiem), Kawalera z fajką (błędnie interpretowanego jako trębacza), Żołnierza grający na piszczałce (flecie), Żołnierza szwedzkiego (kawalera z mieczem), Damę, Saneczki z gąskami. Na piernikach zachowane są ślady polichromii i złoceń. Pierniki były udostępnione jedynie na wystawie toruńskiej w 1954 i 55 r. [Kruszelnicka 1956: 8, 74-78, 84-85].

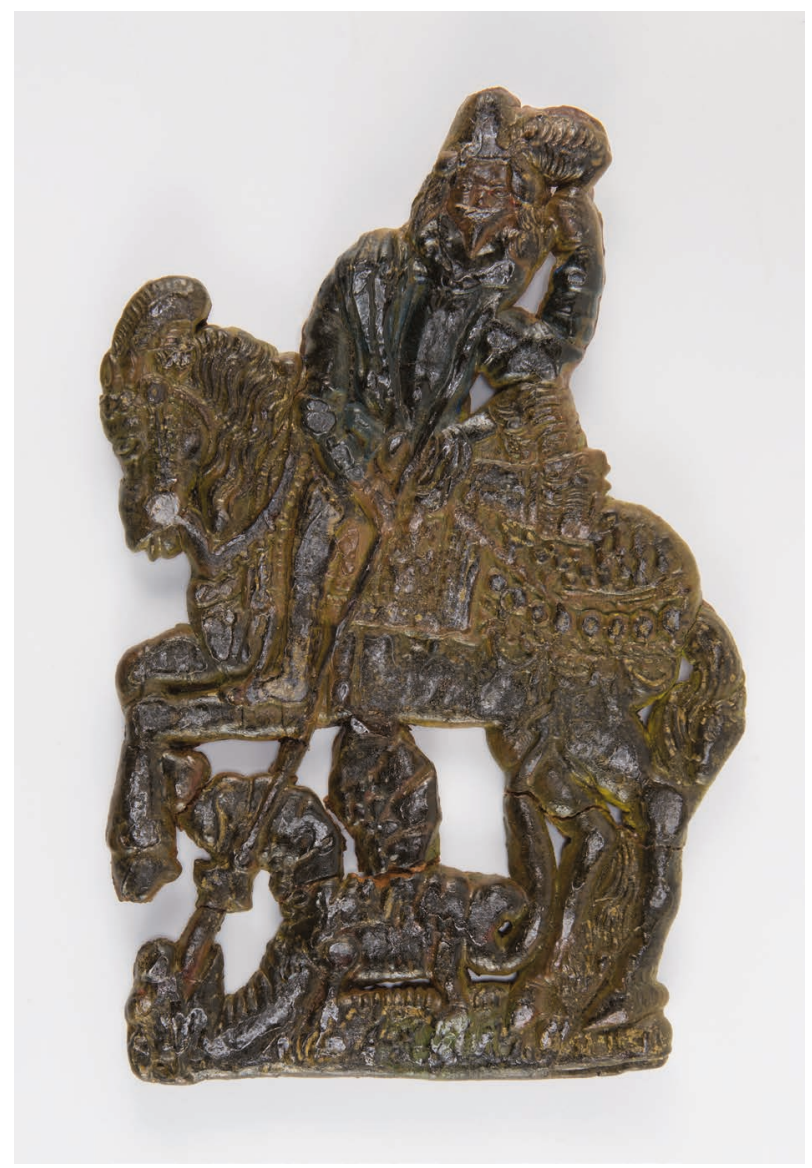

Il. 5. Piernik toruński św. Jerzy - awers, Toruń, firma Gustav Weese, lata 20-30te XX w., przekazane z Muzeum w Rapperswilu, Muzeum Etnograficzne — oddział Muzeum Narodowego w Poznaniu, nr inw. E 920, (Fot. Muzeum Narodowe w Poznaniu)

\footnotetext{
${ }^{22}$ Za konsultacje dziękuję Pani Anecie Skibińskiej - kierownikowi Muzeum Etnograficznego w Poznaniu — oddziału Muzeum Narodowego w Poznaniu.
} 
Il. 6. Piernik toruński św. Jerzy — rewers, Toruń, firma Gustav Weese, lata 20-30te XX w., przekazane z Muzeum w Rapperswilu, Muzeum Etnograficzne — oddział Muzeum Narodowego w Poznaniu, nr inw. E 920, (Fot. Muzeum Narodowe w Poznaniu)

\section{Pierniki w zbiorach w Lodzi}

Muzeum Archeologiczno-Etnograficzne w Łodzi ${ }^{23}$ gromadzi w kolekcji również zespół ośmiu pierników MAEŁ-E-VIII-699-706 pochodzących także, jak informuje wpis na kartach zabytków, „Ze zbiorów w Rapperswilu”. Zostały wpisane do inwentarza w 1953 r. Pierniki powstały przed 1939 r., o czym może świadczyć analogia z piernikami ze zbiorów poznańskich oraz wyciśnięte wzory z zaginionych w czasie zawieruchy wojennej form. Pierniki przedstawiają: Niewiastę (Cecylia Renata) ${ }^{24}$, Damę, Dobosza, Kawalera z pieskiem, Koguta ze zwierzęciem grającym na kobzie, Archanioła Michała, Kawalera z mieczem, Rycerza w stroju antykizującym.

\footnotetext{
${ }^{23}$ Za pomoc w kwerendzie dziękuję Pani dr Barbarze Chlebowskiej oraz Piotrowi i Agacie Burchardtom.

${ }^{24}$ Obiekt określony w karcie jako „Piernik — niewiasta z XVII wieku, w czasie kwerendy zidentyfikowałam jako piernik królewski przedstawiający Cecylię Renatę.
} 


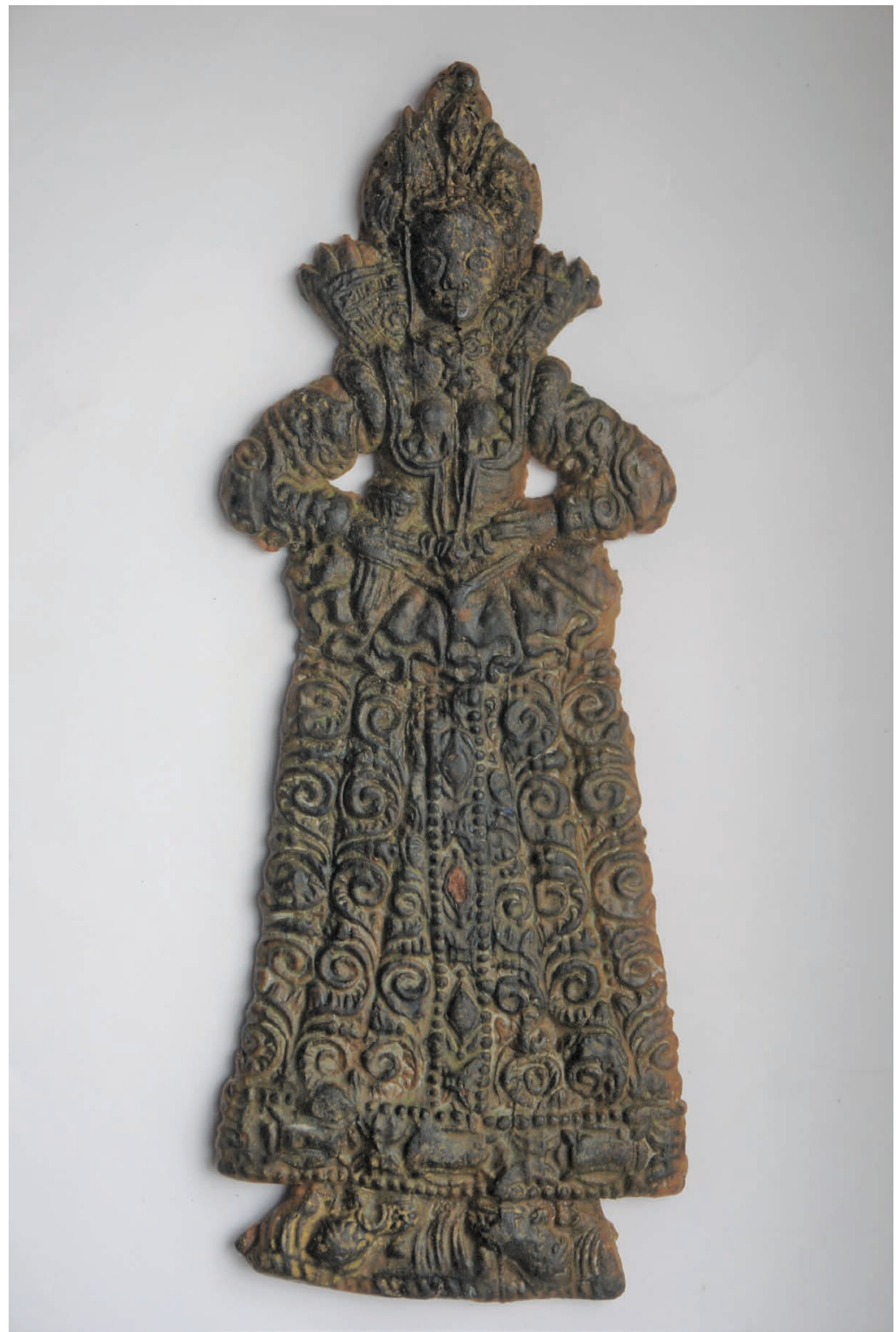

Il. 7. Piernik toruński Dama, firma Gustav Weese, lata 20-30te XX w., z niezachowanej formy piernikarskiej, przekazane z Muzeum w Rapperswilu, Muzeum Archeologiczne i Etnograficzne w Łodzi, nr inw. MAEŁ/E/VIII/700, (Fot. Anna Kornelia Jędrzejewska) 


\section{Pierniki w zbiorach w Chicago}

30 kwietnia w 1939 r. otwarto w Nowym Jorku Wystawę Światową. Polski pawilon wystawy udostępniono 3 dni później. W katalogu prezentującym polską ekspozycję — w dziale C — „rzemiosło artystyczne”25 odnajdujemy informację o umieszczonych na wystawie 36 piernikach toruńskich, do których polichromię wykonał Witold Ulanowski ${ }^{26}$. W opisie czytamy, że tradycje polskiego rękodzieła są podtrzymywane przez twórców toruńskich pierników, którzy nadal w swoich wypiekach zachowują barokowe wzornictwo z XVII i XVIII w. Drewniane formy prezentują drobiazgowość i dokładność snycerki. Natomiast toruńskie pierniki przechowują wspomnienie dawnego tradycyjnego polskiego rzemiosła wspieranego przez zamożne mieszczaństwo ${ }^{27}$.

Po wybuchu II wojny światowej, dekoracyjne wypieki pozostały w Stanach Zjednoczonych i w 1941 r. zostały włączone do kolekcji Muzeum Polskiego w Chicago. Toruńskie pierniki przechowywane w zbiorach Muzeum tworzą obecnie zespół 11 obiektów. Pierwotnie było ich więcej. Osiem z nich ma na odwrociu zapisaną obszerną informację — numer, nazwę oraz określenie pochodzenia: „Wyrób firmy G. Weese — Toruń” a także wzmiankę o autorstwie malunku: „polichromował W. Ulanowski, Warszawa”. Upewnia to w datowaniu obiektów przed 1939 r. Pierniki toruńskie są prezentowane na wystawie stałej oraz prezentowane online ${ }^{28}$. Zespół ten wyróżnia niezwykle starannie opracowana polichromia. Pierniki pomalowano i po-

\footnotetext{
${ }^{25}$ Official catalogue of the Polish Pavilion at World's Fair in New York, Warsaw 1939, https:// polona.pl/item/official-catalogue-of-the-polish-pavilion-at-the-world-s-fair-in-new-york1939,NDYxMjI5NDM/249/\#info:search:Gingerbread,np.s.215, s. 234, data odczytu:12.07.2020; Poland in the World of Tommorow the Polish Pavilion „New York World's Fair”, wn., 1939. Dziękuję Pani Julicie Siegel — kustoszowi i kuratorowi zbiorów Muzeum Polskiego w Chicago, Polish Museum of America za przekazane informacje.https://polona.pl/item/po land-in-the-world-of-tomorrow-the-polish-pavilion-new-york-world-s-fair,NzUwMDExMzc /0/\#info:metadata, data odczytu: 12.07.2020.

${ }^{26}$ Karta 234. Numery od 263 do 298. Osobno zaznaczony był wykonany z ciasta piernikowego statek jako nr 299 (37 piernik), w: Official catalogue of the Polish Pavilion at World's Fair in New York, Warsaw 1939.

${ }^{27}$ Karta 215. Informację o trwałości wzorów XVII i XVIII-wiecznych w piernikarstwie toruńskim podkreślono także w innym katalogu do wystawy, na stornie 13. Zob.: Poland in the World of Tommorow the Polish Pavilion „New York World's Fair”, wn., 1939; https:// polona.pl/item/poland-in-the-world-of-tomorrow-the-polish-pavilion-new-york-world-s-fai r,NzUwMDExMzc/0/\#info:metadata, data odczytu: 12.07.2020.

${ }^{28}$ Obiekty są dostępne w kolekcji online muzeum.: https://polishmuseum.pastperfecto nline.com/search?utf8=\%E2\%9C\%93\&search_criteria=gingerbread\&searchButton=Search, data odczytu: 03.06.2020. O piernikach toruńskich wspomina artykuł: https://www.po lishmuseumofamerica.org/pieces-of-poland-in-its-2nd-capital/ data odczytu: 03.06.2020.
} 


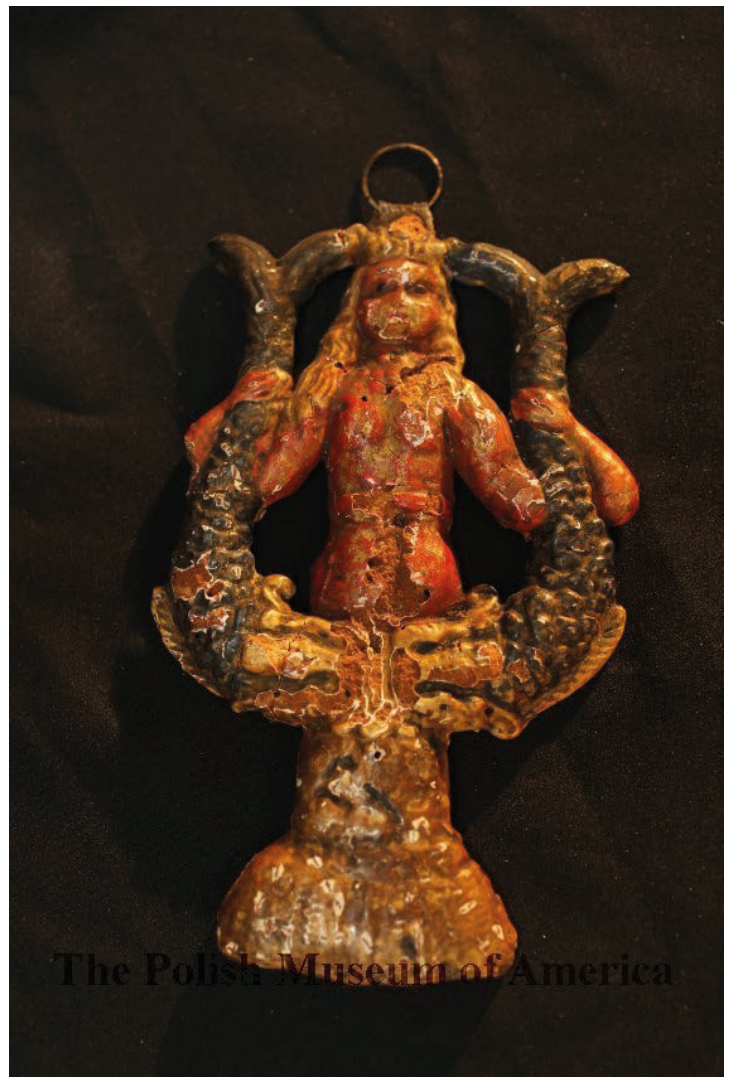

Il. 8. Piernik toruński Syrena - awers, z niezachowanej formy piernikarskiej, Toruń, firma Gustav Weese, przed 1938, polichromia Witold Ulanowski, Muzeum Polskie w Ameryce w Chicago, nr inw. 2018.004.0093, fot.: https://polishmuseum.pastperfectonline. com/webobject/985EE9CC-CD00-4B51 -ABB1-583228000849

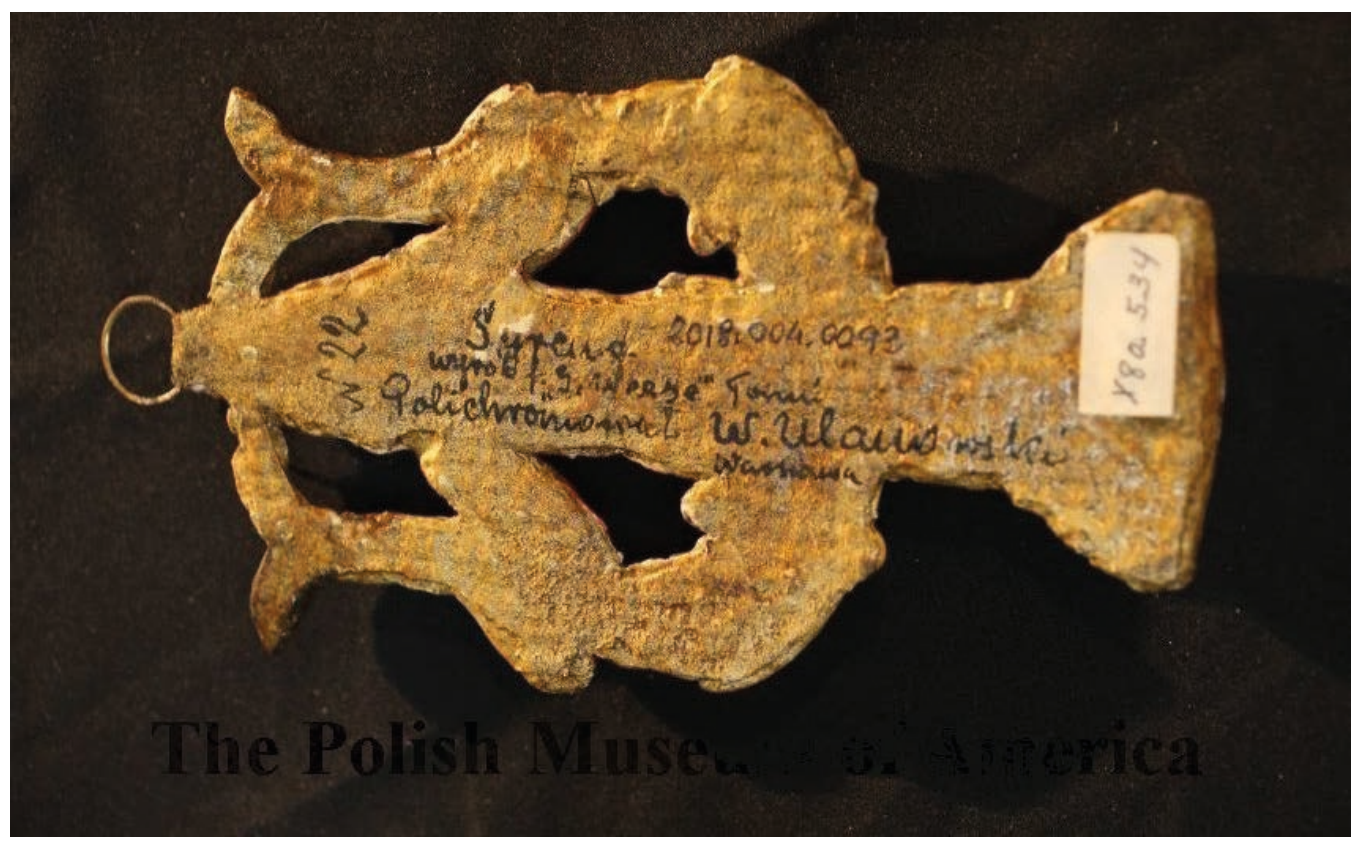

Il. 9. Piernik toruński Syrena — rewers, z niezachowanej formy piernikarskiej, Toruń, firma Gustav Weese, przed 1938, polichromia Witold Ulanowski, zachowana inskrypcja, Muzeum Polskie w Ameryce w Chicago, nr inw. 2018.004.0093, fot.: https://polishmuseum.pastperfectonline.com/ webobject/985EE9CC-CD00-4B51-ABB1-583228000849 
kryto złotem. Doczepiono także zawieszki. Obiekty są starannie opisane. Malunek nawiązywał do tradycji złocenia pierników, z którą spotykamy się w źródłach literackich, jak i wzmiankach archiwalnych. Pierniki przedstawiają: Hołd Trzech Króli, Scenę humorystyczną pod drzewem, Damę jako pasterkę, Syrenę, Saneczki z gąskami, Świętego Mikołaja, Mężczyznę z mieczem, Damę z kądzielą, Statek. Na wystawie ponadto pokazywane są inne wyroby toruńskie z późniejszego okresu (2 sztuki) przedstawiające karetę i wizerunek Cecylii Renaty.

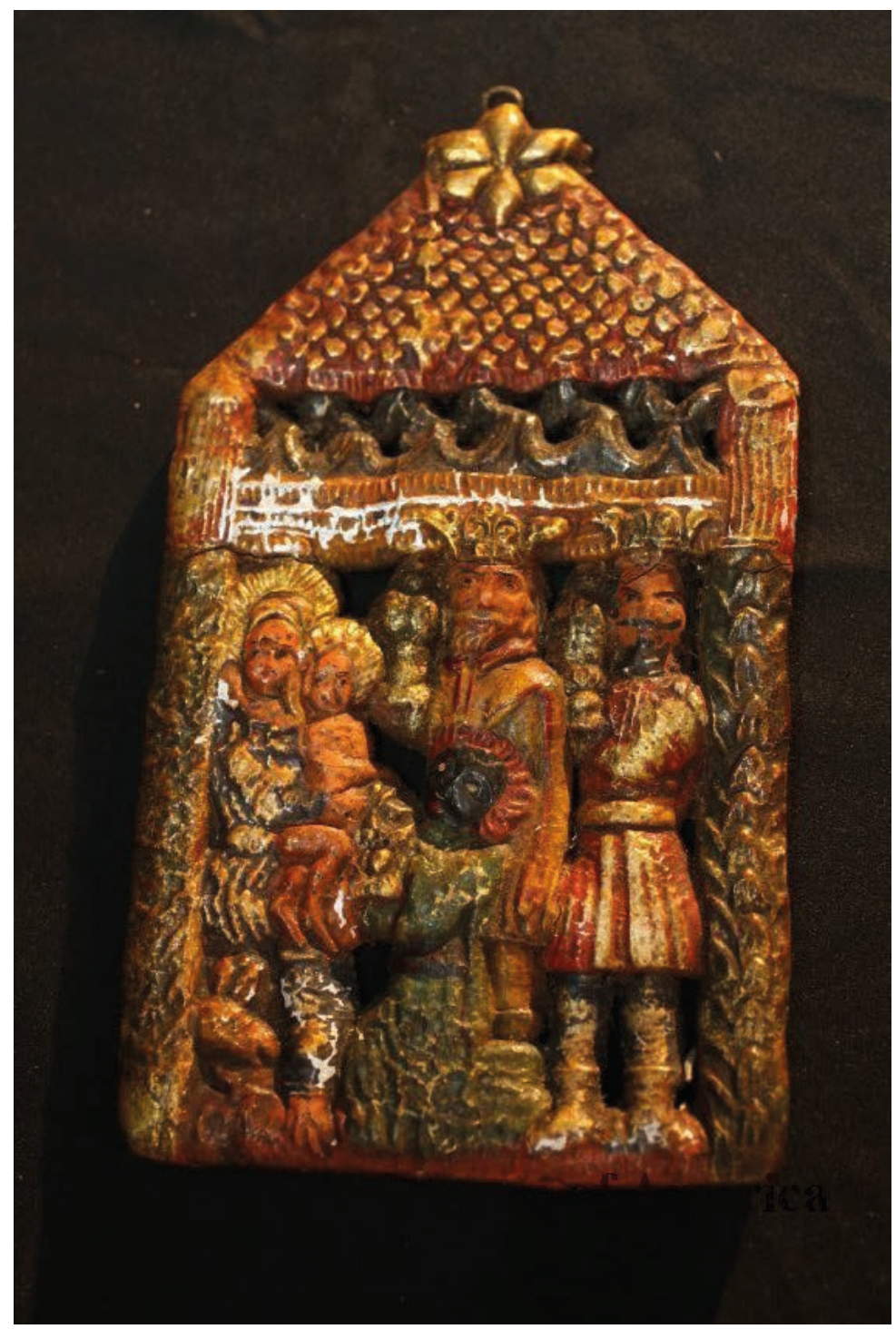

Il. 10. Piernik toruński Hołd Trzech Króli, Toruń, firma Gustav Weese, przed 1938, polichromia Witold Ulanowski, Muzeum Polskie w Ameryce w Chicago, nr inw. 2018.004.0094, fot.: https://polishmuseum. pastperfectonline.com/webobject/9A81A05F-E96F-4CC2-AE22-463471383005 


\section{Pierniki w zbiorach w Londynie}

W Muzeum Hornimana w Londynie znajduję się jeden toruński piernik, przedstawiający prządkę 29 . Piernik ten trafił do zbiorów w 1963 r. Zakupiony został przez kuratora muzeum Otto Williama Samsona, podczas wizyty w Polsce. W tym samym czasie nabył także kolekcję etnograficzną dotyczącą Polski, przygotowaną przez ówczesne Muzeum Kultury i Sztuki Ludowej w Warszawie ${ }^{30}$. W uzasadnieniu funkcji piernika toruńskiego jest opis mówiący o prezentowaniu tego typu pierników jako daru od rodzica chrzestnego dla dziecka. Etykieta umieszczona przy obiekcie informuje o pochodzeniu z okolic Krakowa, Małopolski ${ }^{31}$. Jest to błędne określenie. Piernik pochodzi z formy toruńskiej znajdującej się pierwotnie w zasobach fabryki Herrmanna Thomasa, a potem przekazanej do Muzeum Okręgowego w Toruniu. Warto dodać, że w 1963 r. kiedy Otto W. Samson odwiedzał Polskę, trwał jubileusz 200-lecia toruńskiej fabryki „Kopernik”, będącej najstarszą firmą cukierniczą w Polsce. W Toruniu zorganizowano wówczas okolicznościową wystawę [Jędrzejewska 2020: 212 fot.02], a nakładem Biura Wydawniczego „Ruch” ukazała się seria pocztówek przedstawiająca pierniki toruńskie zaprojektowana przez jednego z wybitnych artystów grafików - Zbigniewa Rychlickiego.

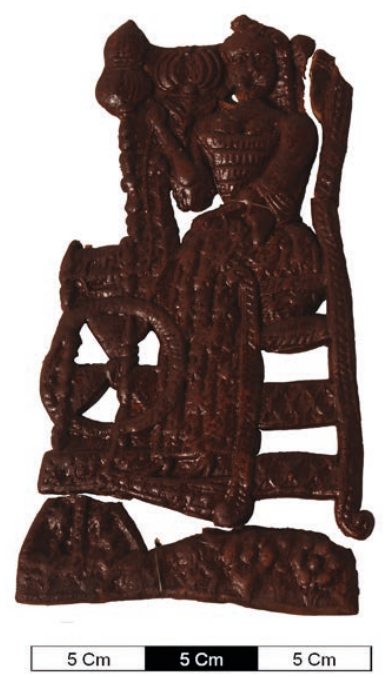

20.11.63/94
Il. 11. Piernik toruński Prządka, Toruń, piernik wypieczony ok. 1963 r., w fabryce pierników, pierwowzór forma drewniana w zbiorach MOT S/767, formy mosiężna i aluminiowa w zbiorach Fabryki Cukierniczej „Kopernik”, Muzeum Hornimana w Londynie, $\mathrm{nr}$ inw. 20.11.63/94, fot.: https://www.horniman. ac.uk/object/20.11.63/94

\footnotetext{
${ }^{29}$ Sygnatura 20.11.63/94.

${ }^{30}$ https://www.horniman.ac.uk/object/authority/agent-4519, data odczytu: 3.06.2020.

${ }^{31}$ https://www.horniman.ac.uk/object/20.11.63/94, data odczytu: 03.06.2020.
} 


\section{Pierniki w zbiorach Muzeum Okręgowego w Toruniu}

Zdziwieniem może napawać brak przedwojennych pierników we współczesnych toruńskich zbiorach muzealnych. Niemniej były gromadzone i przechowywane w muzeum miejskim jeszcze w okresie przedwojennym, o czym świadczą zapisy w inwentarzu muzealnym przechowywanym w archiwum. Pod hasłem: „Holzformen — Honigkuchen” czytamy, że w gablocie znajdowało się 9 sztuk wypieczonych pierników ${ }^{32}$. Nie wiemy czy chodziło o pierniki toruńskie, czy może te wypieczone $z$ form pochodzących z innych ośrodków piernikarskich, a zgromadzonych w muzeum i kojarzonych często błędnie, z toruńską sztuką snycerską ${ }^{33}$. Niemniej domyślamy się, że chodziło o pierniki figuralne. Prawdopodobnie czas II wojny światowej spowodował rozproszenie zbioru.

Obecnie w Muzeum Okręgowym najstarszymi piernikami są te powstałe w ostatniej ćwierci XX w. i zgromadzone w latach 70. XX w. przez starszego kustosza Janinę Mazurkiewicz w Muzeum Mikołaja Kopernika. Od 2012 r. wypieki są systematycznie przekazywane do powstałego w tym samym czasie Działu Historii Toruńskiego Piernikarstwa Muzeum Okręgowego w Toruniu ${ }^{34}$. Do tego zbioru trafiają zabytkowe egzemplarze ofiarowane przez mieszkańców miasta i turystów. W trakcie pracy nad uzupełnieniem kolekcji, kuratorki wspomnianego działu miały okazję spotkać się m.in. Ryszardem Mirowskim, twórcą formy piernikarskiej ${ }^{35} \mathrm{z}$ której wypieczono pierniki dla papieża Jana Pawła II w 1999 r. Ku zaskoczeniu, autor nie tylko podzielił się wiedzą o powstaniu formy, ale także przekazał do zbiorów zachowany kilkunastoletni pamiątkowy piernik. Pracownicy toruńskiego Muzeum Okręgowego nie wpisują pieczywa do inwentarza muzealnego, ale ewidencjonują w księgach pomocniczych. Obiekty objęte są opieką, a także omawianym już zabiegom konserwatorskim.

W kolekcji muzealnej znajdują się również przedstawienia toruńskich pierników wykonane z innych materiałów niż ciasto (gips, wosk, ceramika).

\footnotetext{
${ }^{32}$ APT, AmT, sygn.. E 838, Inwentarz Muzeum Miejskiego w Toruniu. Na stronie nr 49 w dziale: „Holzformen - Honigkuchen”. Pod numerem 41 zapisano „Honigkuchen, gebacken, 9 Stück.”. Pierniki wyeksponowano w gablocie: „Schaukasten Nr. 5.”.

${ }^{33}$ Być może samo ciasto, którego użyto do ukształtowania wypieków pochodziło z toruńskich fabryk?

${ }^{34}$ Obok zbioru pierników, w Muzeum Mikołaja Kopernika (obecnie Dział Domu Mikołaja Kopernika) zbierano opakowania po piernikach toruńskich z logiem Fabryki, na którym znajduje się Mikołaj Kopernik. Zarówno pierniki jak i opakowania przekazano do Działu Historii Toruńskiego Piernikarstwa w latach 2012-2017.

${ }^{35}$ Forma powstała na zamówienie Fabryki Cukierniczej „Kopernik” SA.
} 
W okresie międzywojennym w Toruniu wykonywano gipsowe odlewy z form przedstawiające toruńskie pierniki. Były one malowane i funkcjonowały jako pamiątka oraz towar eksportowy [Mikulska-Wernerowicz, Lewandowski 2020: 77]. Estetyczne walory pierników figuralnych zainspirowały artystów pracujących w Spółdzielni Artystycznej „Rzut”. Popularnością cieszyły się wykonywane przez nich ceramiczne odbitki przedstawiające toruńskie wypieki. Nabywano je jako pamiątkę, prezent lub dekorację. Był to charakterystyczny element wyposażenia toruńskich domów i wnętrz publicznych [Kluczwajd 2002: 10, 26, 33, 41, 57, 60-61].

\section{Wystawy z udziałem pierników toruńskich}

Pierniki wypieczone z ciasta z fabryki Gustawa Weese uzupełniały wystawy stałe i czasowe. Wspomniano o ekspozycji stałej w Muzeum Etnograficznym w Krakowie. Również w Toruniu pierniki pojawiały się na wystawach. Najwcześniejszym, potwierdzonym przykładem sposobu prezentacji zbioru muzealnego form z odbitkami z ciasta, znajdujemy na ekspozycji czasowej „Thorner Kunsthandwerk”, która miała miejsce w dniach 09.08-29.11.1941 w ówczesnym Muzeum Miejskim. Zachowała się dokumentacja fotograficzna autorstwa Kurta Grimma. W gablotach, pod szkłem oraz na ścianach zawieszono drewniane formy piernikarskie oraz podmalowane wypieki. Na jednym zdjęciu jest czytelny podpis na którym umieszczono informację o tym, że prezentowane pierniki zostały wypieczone przez firmę Weese ${ }^{36}$.

W okresie powojennym w Muzeum Okręgowym w Toruniu, na wystawach stałych dotyczących toruńskiego rzemiosła artystycznego, prezentowano formy piernikarskie wraz z ich odciskami powstałymi z gipsu lub ciasta. Dokumentują to zdjęcia Alojzego Czarneckiego z 1947 i 1956 r. ${ }^{37} .28$ listopada 1954 r. otwarto wystawę czasową Pierniki toruńskie. Znane jest zdjęcie prezentujące odlewy gipsowe ${ }^{38}$ oraz opis ekspozycji wspominający o sposobie prezentacji obiektów muzealnych, w tym tych powstałych z ciasta:

\footnotetext{
${ }^{36}$ Zdjęcie A. 1014, autor: Kurt Grimm, 1941 r. — zdjęcie wystawy czasowej. Na fotografii widoczne są formy oraz pierniki z nich wypieczone powieszone obok. Poniżej czytelna informacja: „Die hier augestellten Honiguchen wurden von der Firma Weese - Thorn hergestellt”, zob.:Mierzejewska, Załuska, Markowska 2018: 121, 290; Jędrzejewska 2018b: 208, 213.

${ }^{37}$ Wystawa Toruńskie rzemiosło artystyczne, 27 III 1956 r., fot. A. Czarnecki, ze zbiorów Archiwum Muzeum Okręgowego w Toruniu; Wystawa Toruńskie rzemiosło artystyczne XVII-XIX, 17 VII 1947 r., fot. A. Czarnecki, ze zbiorów Archiwum Muzeum Okręgowego w Toruniu, obie reprodukowane w: Jędrzejewska 2018b: 213-214, il. 5 i 6.

${ }^{38}$ Pierniki toruńskie, 1955 r., fot. A. Czarnecki, ze zbiorów Archiwum Muzeum Okręgowego w Toruniu, zob. Jędrzejewska 2018b: 210.
} 

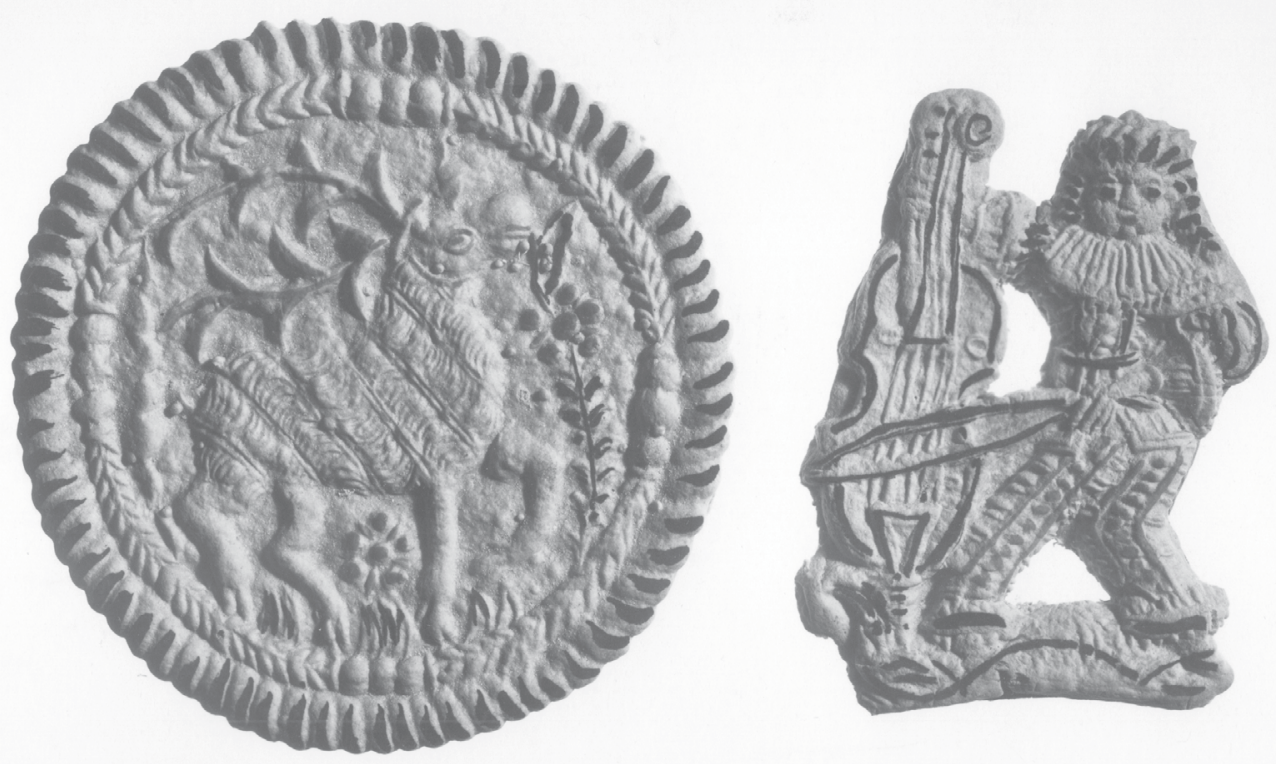

Il. 12. Fotografia pierników, wypieczonych z toruńskiego ciasta w Fabryce Weese i eksponowanych na wystawie „Toruńskie rzemiosło artystyczne” w Muzeum Miejskim w Toruniu. Kształty uformowano z klocków z Nowego Dworu Gdańskiego i Pasłęka włączonych do kolekcji Muzeum Okręgowego w Toruniu, wrzesień 1941, fot. Kurt Grimm, A.1020, wł. Muzeum Okręgowe w Toruniu

Osobny problem stanowiło przedstawienie pierników toruńskich na tle materiału porównawczego z innych ośrodków polskich i zagranicznych. [...] Wystawę umieszczono w Sali I piętra zachodniego skrzydła. Formy piernikowe, odlewy gipsowe z form i wypieki z ciasta eksponowano w wiszących witrynach wyłożonych jutą w kolorze złocistym, doskonale podkreślającym plastykę brązowych form i wypieków z ciasta [Załęska 1962: 45-46].

4 czerwca 1978 r. w Piwnicy gdańskiej Ratusza Staromiejskiego w Toruniu odbyła się wystawa pt.: Pierniki $w$ dawnej Polsce, prezentująca kolekcje form piernikarskich z kilkunastu ośrodków w kraju. W ramach zorganizowanej biesiady odbyły się dwa odczyty, jeden o historii fabryki w Toruniu oraz wypieku pierników historycznych oraz drugi o historii cechu i zabytkowych formach piernikowych. Ciekawa uwaga ukazała się na łamach prasy w recenzji wystawy czasowej „Na wystawie nie ma — a szkoda — pierników, poza oczywiście brzydkimi atrapami z gipsu. Są natomiast cudowne, 
stare i nowe formy, rzeźbione w drewnie" [Marciniak 1978]. Równolegle organizowano wystawy czasowe w kraju i zagranicą ${ }^{39}$.

W 2006 r. otwarto pierwszą muzealną stałą wystawę poświęconą lokalnemu piernikarstwu pt. Świat toruńskiego piernika, a w $2015 \mathrm{r}$. Muzeum Toruńskiego Piernika - oddziału Muzeum Okręgowego w Toruniu dedykowanego tej tematyce ${ }^{40}$. Zarówno we wspomnianych przestrzeniach jak i organizowanych od 2008 r. wystawach czasowych w całej Polsce, aranżację uzupełniano o gipsowe kopie pierników królewskich (wykonanych na podstawie odbitek zachowanych w Krakowie), ceramiczne odciski z form wykonanych we wspomnianej spółdzielni „Rzut”, a przede wszystkim dekoracyjne wypieki zrobione współcześnie z ciasta niespulchnionego w Fabryce Cukierniczej „Kopernik”. Z tego samego, z którego wypiekane są pamiątkowe, historyczne specjały, będące nadal w sprzedaży.

\section{Wykonanie. Stan zachowania}

Najstarsze pierniki toruńskie w zbiorach muzealnych mają blisko sto lat. Biorąc pod uwagę wiek, ich stan zachowania jest zadawalający. Wypieczone z ciasta na bazie mąki, miodu i mieszanki korzeni obiekty szczególnie były i są narażone zarówno na zmianę warunków przechowywania takich jak wilgotność czy temperatura (możliwość rozwoju pleśni). Materiał z którego powstawały, jest kruchy — stąd często zdarzały się uszkodzenia mechaniczne (np. przy przekładaniu, wypożyczaniu). Na piernikach widoczne są pęknięcia, często odłamane fragmenty szczególnie w partii delikatnej, ażurowej części piernika np., wystającej kończyny lub fragmentu trzymanego przedmiotu. Zauważalne są ślady łączeń elementów, sklejania ich, wzmacniania całej konstrukcji innymi tworzywami. W niektórych piernikach, szczególnie tych malowanych i złoconych widoczne są uszkodzenia polichromii, ukruszenia warstwy powierzchni. Pierniki są podmalowywane na brązowe kolory, co jest widoczne szczególnie na odwrociu

\footnotetext{
${ }^{39} \mathrm{O}$ prezentacji form piernikarskich: Kukowicz-Wirowska, Jędrzejewska 2014 oraz Mikulska-Wernerowicz, Lewandowski 2020.

${ }^{40}$ Otwarcie wystawy Świat toruńskiego piernika miało miejsce 24 czerwca 2006 r. w Domu Mikołaja Kopernika. Autorkami scenariusza są Barbara Kukowicz-Wirowska, Maria Magdalena Gessek, za aranżację plastyczną odpowiadał Stanisław Lackowski, 25 listopada 2008 r. ten sam zespół kuratorski zrealizował wariant wędrujący wystawy. Następnie 19 czerwca 2015 r. w dawnej fabryce pierników rodziny Weese, przy ulicy Strumykowej 4 otwarto Muzeum Toruńskiego Piernika - oddział Muzeum Okręgowego w Toruniu. Kuratorkami projektu są Barbara Kukowicz-Wirowska, Anna Kornelia Jędrzejewska. Więcej o projekcie: Kukowicz-Wirowska, Jędrzejewska 2014; Jędrzejewska 2020, Mikulska-Wernierowicz, Lewandowski 2020.
} 
piernika, gdzie widoczna jest oryginalną kolorystyka ciasta i odciśnięta faktura blachy (?) lub innego podłoża na którym były wypiekane. Zachowane są także fragmenty złoceń.

Dotkliwe są uszkodzenia powodowane przez insekty, szczególnie mole spożywcze. Brak szybkiej reakcji konserwatorskiej mógł doprowadzić do degradacji i zniszczenia obiektu, co zresztą miało miejsce w różnych omawianych kolekcjach. Część pierników po zniszczeniu, trzeba było usunąć z inwentarza. Praktyką było wymrażanie pierników. Otwory wypełniano i zaklejano. W trakcie prowadzonej kwerendy pracownicy zadawali pytania o praktykę stosowaną w innych muzeach. Wydaje się, że szczególnie cenne w kontekście omawianej tematyki byłoby nawiązanie kontaktu, wymiana wiedzy pomiędzy pracownikami poszczególnych instytucji, a może nawet stworzenie platformy badawczej koncentrującej się na piernikarstwie w Polsce, również w zakresie opieki nad zabytkami oraz praktyki konserwatorskiej. Niewątpliwie usprawniłoby to komunikację i wzbogaciło stan badań nad gromadzonymi zabytkami. Należy jednak podkreślić, że to dzięki umiejętnościom i staraniom kolejnych pokoleń pracowników muzeów, pierniki przetrwały do współczesnych czasów.

\section{Ikonografia}

„Formy piernikarskie są interesującymi źródłami historycznymi, głównie ikonograficznymi, do poznania dziejów kultury materialnej” — wspomina Krzysztof Maciej Kowalski, dodając, że „formy piernikarskie, podobnie jak tłoki mennicze (mincerskie) czy pieczątne, są trwałymi przekazami ikonograficznymi pewnego zapisu obrazowego - utrwalonego jednak zgodnie z przeznaczeniem i pełnioną przez nie w procesie produkcyjnym funkcją — w postaci negatywu” [Kowalski 1993: 104]. W dalszej części wskazuje na konieczność prowadzenia analizy tego zapisu nie na formie ale na odcisku — czyli np. na pierniku. Dopiera analiza płaskorzeźby wypukłej ciasta daje nam pełny obraz koncepcji artystycznej zamierzonej przez twórcę [Kowalski 1993: 104].

Zakres wzorów i motywów omawianych toruńskich pierników jest bardzo szeroki i bogaty. Nie sposób w niniejszym opracowaniu wyczerpać tematyki. Do kanonu przedstawień kojarzonych z piernikarstwem toruńskim należą herb Torunia, pierniki królewskie, kareta, prządka oraz katarzynka. W niniejszym opracowaniu warto przyjrzeć się temu ostat- 
niemu motywowi, który do tej pory nie został szerzej zbadany i poddany analizie porównawczej.

Najsłynniejszym toruńskim piernikiem jest katarzynka, powstała z sześciu okrągłych motywów połączonych ze sobą. Zarówno nazwa, jak i kształt tego wypieku znany był także w innych ośrodkach piernikarskich. Niemniej to w Toruniu motyw ten nie tylko został na trwałe, ale nawet ewoluował z figuralnego piernika historycznego do współczesnego piernika konsumpcyjnego. Katarzynka jest przykładem udanego transferu i adaptacji pieczywa przedstawiającego do wypieku o charakterze spożywczym. Współczesny kształt w zarysie odwołuje się do dawnej formy. Przekształcenia tej formy na podstawie opracowania Janiny Kruszelnickiej zaproponował Mateusz Magalski [2014: 126]. Warto dodać, że forma do katarzynki nadal ulegała ewolucji, przechodząc fazy z drewnianego klocka z wyodrębnionymi postaciami figuralnymi ${ }^{41}$, poprzez uproszczenie wzoru do ornamentu florystycznego i geometrycznego, następnie wzmocnionego blachą, aż do - co chciałabym zaproponować - metalowego lub współcześnie plastikowego (ze sztucznego tworzywa) wycinaka, schematycznie już naśladującego pierwotny motyw.

Piernik nazywany katarzynką kojarzony był ze wspomnieniem świętej Katarzyny Aleksandryjskiej, które przypada na 25 listopada. Zwyczajowo ten dzień był w Toruniu symboliczną datą rozpoczęcia wypieku pierników [Kujot 1884: 93; Kruszelnicka 1956: 26]. Z tego względu piernik toruński mógł mieć także charakter pieczywa odpustowego, nabywanego z okazji udziału w świątecznym jarmarku i zabieranego do domów ${ }^{42}$. W Toruniu nie zachowały się formy przedstawiające figurę św. Katarzyny ${ }^{43}$. Znane są jednak przykłady wypiekania pieczywa przedstawiającego wizerunek świętej. Formą z jej przedstawieniem znajduje się w zbiorach Muzeum Londynu (Museum of London) ${ }^{44}$. Opis zawiera prezentację obiektu, dodane są podstawowe dane dotyczące czasu powstania oraz nawiązanie do tradycji

\footnotetext{
${ }^{41}$ W Muzeum Okręgowym w Toruniu przechowywana była forma S/933, przedstawiająca motywy roślinne i zwierzęce. Forma zaginęła.

${ }^{42}$ Janina Kruszelnicka wspomina, że w „Gazecie Toruńskiej” z 6 lipca 1884 r. znajduje się wzmianka, że na jarmarkach toruńskich naklejano obrazki świętej na piernik. Zob. Kruszelnicka 1956: 26. O piernikach odpustowych pisali m.in.: Wójcik 1966: 203-215; Ambrożewicz 1978:, 81-90. Szelągowska 2020.

${ }^{43}$ Znane są jednak inne postacie świętych: m.in. św. Jerzy, św. Michał Archanioł, św. Mikołaj.

${ }^{44}$ Ceramiczna forma do słodyczy figuralnych przedstawiająca wizerunek św. Katarzyny Aleksandryjskiej, poł. XVI-pocz. XVI wieku, numer inwentarzowy A11480, obiekt z kolekcji Museum of London. https://collections.museumoflondon.org.uk/online/object/37595.html, data odczytu: 03.06.20.
} 
wypiekania przysmaków na jarmarki z okazji dnia świętej. Inne badania prowadzone metodą kwerendy internetowych baz zasobów cyfrowych dziedzictwa kulturowego wskazują na występowanie piernika o zbliżonym kształcie w Austrii („Pięciomigdałówkę”, „Fünfmandlern” — produkuje znana firma Pirker ${ }^{45}$. W niemieckiej miejscowości Berchtesgaden (przy granicy z Austrią), tradycyjnym pieczywem jest tzw. „sztuka” (Stuck), składająca się z sześciu bułkowatych kształtów połączonych ze sobą parami w trzech rzędach ${ }^{46}$. Jest to wypiek zaliczany do kategorii Gebildbrote, czyli ozdobnego pieczywa figuralnego, przedstawiającego, obrzędowego. Bułki odrywa się od całości i zjada w gronie rodzinnym. W ikonografii form służących do kształtowania pierników, wyróżnia się typ tzw. „form szeregowych, rzędowych, linijkowych” (Zielenmodel), w którym poszczególne elementy, powtarzając się, tworzą rzędy. Funkcją tych form jest ukształtowanie wypieku, tak aby można się nim było łatwo podzielić [Fischer 2013: 122-124]. Warto zwrócić także uwagę na przedchrześcijańskie znaczenie symbolu wirującego koła, rozety lub wianka z kwiatami oznaczającego w dużym skrócie płodność, ruch, zmianę, pory roku, solarne i lunarne, astralne, akwatyczne, magiczne symbole, nawiązujące do ruchu kosmosu i sił przyrody.

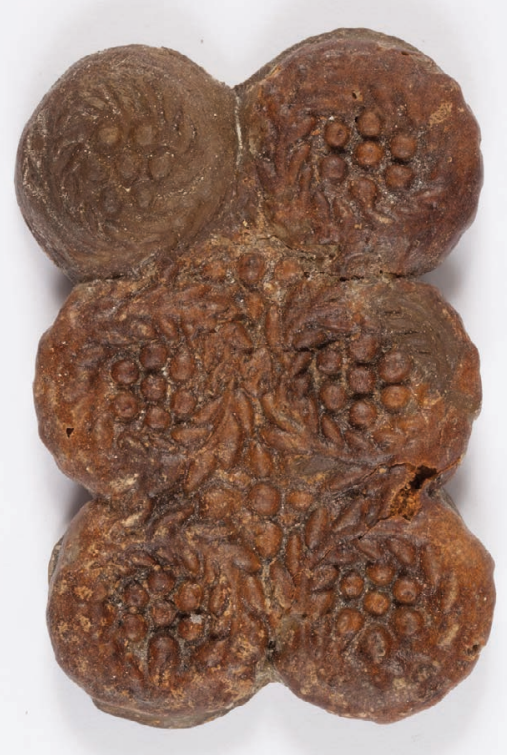

Il. 13. Piernik toruński — katarzynka awers, 1925 r., Toruń, firma Herrmann Thomas, Muzeum Etnograficzne im. Seweryna Udzieli w Krakowie, nr inw. 4474/MEK, (Fot. MEK)

\footnotetext{
${ }^{45} \mathrm{https}$ ://www.lebkuchen-pirker.at/de/funfmandler, data odczytu: 03.05.2020.

${ }^{46}$ Więcej o „Sztukach” (,Stuck”) - tradycyjnym pieczywie z Berchtesgaden: https://www. berchtesgadeninfo.de/de/kultur-brauchtum-alpen/kulinarisches/der-stuck.html, data odczytu: 04.05.2020.
} 


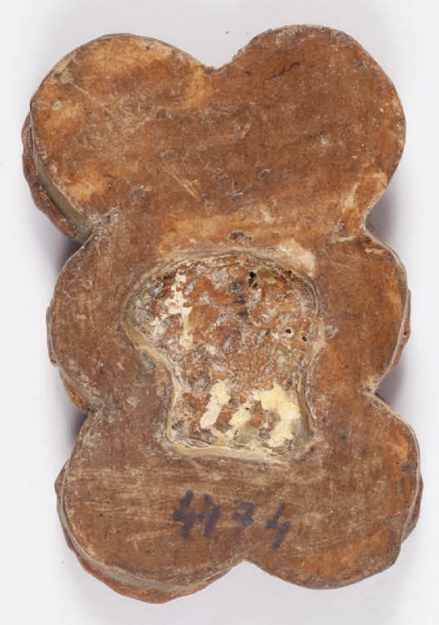

Il. 14. Piernik toruński - katarzynka rewers 1925 r., Toruń, firma Herrmann Thomas, widoczne wzmocnienia oraz ślady zabiegów konserwatorskich, Muzeum Etnograficzne im. Seweryna Udzieli w Krakowie, nr inw. 4474/MEK, (Fot. MEK)

Dzięki analizie danych wyszukanych w cyfrowych bazach danych i repozytoriach, można wysnuć przypuszczenie, że katarzynka jest rodzajem pieczywa odpustowego, pierwotnie przygotowywanego z okazji dnia świętej Katarzyny, figuralnego piernika dzielonego, którego forma pozwala na łatwość podziału na mniejsze części. Jako jedyny toruński piernik figuralny został przekształcony do współczesnej wersji wypieku spulchnionego, jadalnego, w wersji z czekoladą i bez. Ciasto na katarzynki było dawniej prawdopodobnie takie samo jak na inne pierniki. Obecnie jest to już określona i zastrzeżona receptura — wraz z kształtem — dla Fabryki Cukierniczej „Kopernik” SA.

W Toruniu w XX w. powstały legendy mające na celu wyjaśnienie pochodzenia charakterystycznego piernika ${ }^{47}$. Opowieści te są przekazywane mieszkańcom miasta i turystom także podczas współcześnie prowadzonych

\footnotetext{
${ }^{47}$ Istnieje także wiele XX-wiecznych legend o Katarzynie zakonnicy lub córce piernikarza, która stworzyła te pierniki, albo miała być inspiracją do ich powstania (dwa serca i obrączki połączone ze sobą). Zob.: Bobecka 2012.
} 
w muzeach i piernikarniach działań edukacyjnych, spotkań i warsztatów. Sprzyjają kontynuowaniu pamięci o tradycjach piernikarskich, wzmacniając postrzeganie Torunia jako piernikarskiej stolicy w Polsce i w Europie (obok Norymbergi).

\section{Rola i funkcja toruńskich pierników figuralnych}

Pierne pieczywo z Torunia było znane w Toruniu co najmniej od XIV wieku. W XVII wieku chwalono jego smak. Zaliczano do najpopularniejszych w kraju produktów i symbolu najlepszej jakości. W opracowaniach encyklopedycznych przy omawianiu Torunia często wskazywano na miasto jako ośrodek piernikarski. Natomiast w hasłach dotyczących pierników można było znaleźć informacje, że toruńskie wyroby były słynne, sławne. Działania władz miasta wzmacniały pozycję toruńskiego rzemiosła i przemysłu piernikarskiego, m.in. poprzez wręczanie pierników, jako oficjalny dar od mieszkańców miasta. Ponadto pełniły one funkcje m.in. przekąski, przysmaku, lekarstwa, dekoracji oraz pamiątki [Jędrzejewska 2018a: 186-196]. Do dzisiaj stanowią rozpoznawalny element dziedzictwa kulinarnego w Polsce ${ }^{48}$.

Ciasto na pieniki figuralne pozbawione było spulchniaczy. W ten sposób zachowywano jego kształt. Niemniej nadal cieście znajdowały się cenne i drogie przyprawy korzenne. W takim znaczeniu wypiek mógł stanowić „magazyn” mieszanki przyprawowej. W razie potrzeby starty dekoracyjny piernik mógł być wykorzystany jako dodatek do sosów (zarówno przy mięsach jak i rybach) czy panierka ${ }^{49}$. O użyciu piernika w tym charakterze wspominają książki kucharskie, na ten element wskazują badacze dziejów kulinarnych ${ }^{50}$.

Jednym z najstarszych świadectw wypieku pierników figuralnych w Toruniu są formy — narzędzia używane do kształtowania korzennego ciasta. Najstarsze są datowane na XVII wiek. Toruńskie wypieki przedstawiające, miały rozbudowane znaczenie, poszerzone o wizualny kontekst. Mogły stanowić dekorację, ozdobę stołu lub wnętrza. O tej funkcji wspomina

\footnotetext{
${ }^{48}$ Toruńskie pierniki pojawiły się w opracowaniu dr Magdaleny Tomaszewskiej-Bolałek, która włączyła je do kanonu polskich potraw w opracowaniu „Polski stół”. https://bunka tura.pl/the-polish-table/, data odczytu: 15.11.2020.

${ }^{49}$ „Piernik gastronomiczny” - produkt stworzony jako dodatek do innych potraw przez toruńskiego cukiernika Adama Pokojskiego we współpracy z prof. Jarosławem Dumanowskim,

${ }^{50}$ Dumanowski 2010 i 2016, Kleśta-Nawrocka 2016.
} 
Maria Żywirska prowadzące pionierskie badania nad dziejami piernikarstwa w Polsce:

Często nabywano pierniki jedynie dla ozdoby. Poczesne miejsce, jakie zyskał piernik wędrując prze stoły wszystkich warstw społecznych od królewskiego po chłopską chatę — zawdzięczał nie tylko walorom wyszukanego smaku, ale także różnorodności swego kształtu. Kształt ten, czasem obwarowany tradycją, uzyskiwano przez odciśnięcie ciasta piernikowego w drewnianej formie, pokrytej wklęsłą rzeźbą o skomplikowanej symbolice. Dzięki walorom artystycznym tych rzeźb, słodki piernik zamieniał się w dzieło sztuki dekoracyjnej [Żywirska 1957: 69-70].

Za danym kształtem, kryły się treści, czytelne dla danej grupy odbiorców. Poprzez ukształtowanie ciasta w wybrany wizerunek nadawano mu konkretne znaczenie i przekształcano w niewerbalny komunikat [Berendt 2005: 149]. Anna Rumińska proponuje rozumienie piernika figuralnego przedstawieniowego jako „tekstu kultury”, który należy odczytywać51. W tym kontekście wręczanie toruńskiego piernika figuralnego, nabierało podwójnego znaczenia. Nie tylko wiązało się z wręczeniem daru, upominku, ale także z przekazaniem określonej informacji.

Widoczne jest to na przykład w przypadku wypieków z wizerunkiem herbu Torunia. Pierniki o tym kształcie szczególnie podkreślały związek wypieku z nadwiślańskim miastem. O popularności motywu świadczy to, że jest to obok katarzynki najczęściej występujące przedstawienie na klockach piernikarskich z Muzeum Okręgowego w Toruniu czy Fabryki. Przeprowadzone badania wykazały, że również w innych muzeach w Polsce odnajdujemy formy z tym motywem ${ }^{52}$. Czasem tak dalece przekształconym, że trudno dopatrzeć się w nim oryginału. Może to świadczyć o uznaniu dla toruńskich wyrobów, które próbowano naśladować. Przedstawienie to ewoluowało w lokalnych ośrodkach tworząc zupełnie nieznane dla Torunia warianty. Nabycie wypieku w kształcie herbu Torunia niosło zatem komunikat o zakupie prawdziwego toruńskiego piernika.

\footnotetext{
${ }^{51} \mathrm{https}$ ://artecubo.pl/blog/kuchnia-pachnaca-piernikiem-slow/, data odczytu: 16.07.2020.

${ }^{52}$ Takim przykładem są formy zachowane w kolekcjach muzeów: Zamek w Kwidzynie oddział Muzeum Zamkowego w Malborku, Muzeum Warmii i Mazur w Olsztynie, Muzeum Etnograficzne im. Seweryna w Krakowie, Muzeum Etnograficze — oddział Muzeum Narodowe w Poznaniu, Muzeum Początków Państwa Polskiego w Gnieźnie. W kolekcji Muzeum Etnograficznego oddziału Muzeum Narodowego we Wrocławiu występuje forma z motywem określanym jako herb Torunia, niemniej po analizie ikonograficznej należy wykluczyć związek tego przedstawienia z Toruniem.
} 


\section{Znaczenie toruńskich pierników figuralnych dla dziedzictwa materialnego i niematerialnego Torunia oraz lokalnej tożsamości i pamięci torunian}

„Sława toruńskiego piernika była tak powszechna i niepodzielna, że zaćmiła niemal zupełnie inne ośrodki kunsztu piernikarskiego w Polsce. Począwszy od XVI w., piernik toruński zajmował miejsce niepoślednie w obyczajach ówczesnej Polski stanowej” — pisała Maria Żywirska [1957: 69]. Co wpłynęło na takie postrzeganie omawianych wypieków? Z jednej strony jak wspomniano chodziło o smak z drugiej o walory estetyczne produktu. Istotne znaczenie ma także nieprzerwany od XIV w. zwyczaj wypiekania piernikowych wyrobów. Tradycje najstarszej działające fabryki cukierniczej w Polsce nawiązują do roku 1763. Przez kolejne wieki zmieniali się właściciele warsztatów i przedsiębiorstw, niemniej pracujący w nich mieszkańcy Torunia, pozostawali, przekazując wiedzę o dawnych sposobach wypiekania pierników. Przykładem takiego procesu jest postać mistrza piernikarskiego Konrada Szwarca, dzięki którego relacji znamy lepiej realia pracy piernikarzy toruńskich przed II wojną światową³. Wiele osób pracujących w fabrykach toruńskich, pozostało w Toruniu, przekazując pamięć o sposobach pracy kolejnym pokoleniom., czy dzieląc się wspomnieniami w gronie rodzinnym ${ }^{54}$.

W Toruniu nie wyodrębnił się osobny cech piernikarzy jak to miało miejsce w Krakowie, we Wrocławiu czy Warszawie. Najstarsza wzmianka o wypieku pierników w Polsce jest związana ze Świdnicą i rokiem $1293^{55}$. Niemniej to w Toruniu pamięć o dziedzictwie piernikarskim nie tylko przetrwała, ale także nadal jest twórczo kontynuowana przez kolejne pokolenia piernikarzy

\footnotetext{
${ }^{53}$ Relację mistrza Szwarca spisał Michał Samulski (1909-1990) — wieloletni dyrektor Fabryki Cukierniczej „Kopernik”. Samulski opracowywał historię toruńskiego rzemiosła i przemysłu piernikarskiego. Z jego inicjatywy przekazano m.in. historyczne formy do Muzeum Okręgowego w Toruniu. Por.: Sudziński, Samulski, 1971. Dokumenty ofiarował do Działu Historii Toruńskiego Piernikarstwa wnuk Samulskiego Piotr Rozwadowski.

${ }^{54}$ Takie relacje zbierają pracownicy Działu Historii Toruńskiego Piernikarstwa. Obecnie w dziale pracują Małgorzata Mikulska-Wernerowicz - kierownik, oraz adiunkci dr Aleksandra Kleśta-Nawrocka i Krzysztof Lewandowski.

${ }^{55} \mathrm{https}$ ://slowfooddolnyslask.org/produkty/pierniki/pierniki-dolny-slask-piperatas-torta s-swidnica/, data odczytu: 16.07.2020. W wielu miastach odkrywana jest na nowo lokalna tradycja wypieku pierników, m.in. w Jaworze (Teresa Chołubek-Spyt, Arkadiusz Muła, czynna jest kawiarenka piernikowa przy Muzeum Regionalnym w Jaworze), Bardzie (Tomasz Karamon - snycerz i twórca projektu Bardzkie Pierniki, kawiarenkę z piernikami wypiekanymi według dawnych bardzkich przepisów prowadzi twórczyni ludowa Magdalena Topolanek), Niemczy (Karolina Klimek, Piernikarnia Śląska), Pasłęka (Piotr Adamski). Więcej na ten temat: Jędrzejewska 2020.
} 
pracujących zarówno w Fabryce „Kopernik”, jak i prowadzących własne warsztaty, czego przykładem może być działalność rodziny Pokojskich ${ }^{56}$, których członkowie praktykowali także we wspomnianych zakładach cukierniczych. Organizowane przez pracowników muzeum miejskiego, a potem okręgowego w Toruniu wystawy stałe i czasowe zarówno w Toruniu, jak i w innych miastach Polski i Europy ${ }^{57}$ sprzyjały popularyzacji wiedzy o dawnym i współczesnym piernikarstwie. Ważnym elementem w budowaniu wizerunku miasta miała kontynuacja wypieku historycznych pierników figuralnych. Ich kształty, zachowane w XVII-XVIII-wiecznych formach przechowanych w muzeum i fabrykach, inspirowały kolejne pokolenia artystów, którzy w twórczy sposób przekształcali je w swojej działalności. Warto wspomnieć o artystach tworzących pierniki ceramiczne, naczynia i kilimy w spółdzielni „Rzut” [Kluczwajd 2002], projektujących witraże $^{58}$, wykonujących ilustracje ${ }^{59}$ i elementy w przestrzeni miasta ${ }^{60}$. Również dzisiaj współcześni twórcy nadal czerpią z tego aspektu dziejów miasta ${ }^{61}$, niektórzy podjęli się kontynuacji tradycji w zakresie np. snycerki piernikarskiej. Znaczące jest także występowanie dużej liczby gadżetów i pamiątek związanych z piernikami, często niestety dość niskiej jakości. To zagadnienie wymaga jednak odrębnego spojrzenia.

W niniejszym artykule poruszano kwestię ochrony dziedzictwa materialnego związanego z piernikarstwem toruńskim. W tym zakresie ważną rolę pełnią muzea. W Toruniu proces nabywania form piernikarskich do zbiorów muzealnych rozpoczął się co najmniej w 1908 r. Od tego czasu

\footnotetext{
${ }^{56}$ Cukiernia Franciszek Pokojski w Toruniu. Historia piekarzy i cukierników z tej rodziny sięga 9 listopada 1932 r., http://www.pokojski.com.pl/index.php?p=1\&s=2, data odczytu: 03.06.2020. Od 1956 r. zakład działa w Toruniu, od trzech pokoleń jest prowadzony przez kolejnych członków: Franciszka I, Franciszka II, Adama i Grażynę.Dziękuję Panu Adamowi i Pani Grażynie Pokojskim za pomoc w kwerendzie i udzielenie informacji. W ofercie firma ma także pierniki figuralne inspirowane historią Torunia. http://www.pokojski.com.pl/ index.php?p=2\&s=5, data odczytu: 03.06.2020.

${ }^{57} \mathrm{O}$ prezentacji form piernikarskich: Kukowicz-Wirowska, Jędrzejewska 2014; Jędrzejewska 2018b; Jędrzejewska 2020, Mikulska-Wernerowicz, Lewandowski 2020.

${ }^{58}$ Autorami witraży, znajdujących się we wnętrzach dworca PKP w Toruniu inspirowanych historycznymi piernikami figuralnymi byli: Zdzisław Kulikowski, Edward Kwiatkowski, a także Romuald Drzewiecki [Hudzik 2018: 176].

${ }^{59}$ M.in. Irena Kuczborska, Zbigniew Rychlicki, Bożena Truchanowska-Majchrzak, Janina Krzemińska, Jerzy Wróblewski.

${ }^{60}$ Maria Hoffmann zaprojektowała fryz w technice sgraffito z motywami piernikarskimi na fasadzie na kamienicy przy ul. Szeroka 38.

${ }^{61}$ Henryk Jerzy Chmielewski „Papcio Chmiel”, Bohdan Butenko, Ryszard Kaja, Małgorzata Wojnowska-Sobecka, Dariusz Przewięźlikowski, Tadeusz Porębski (twórca rzeźby Piernikarki). W Toruniu znajduje się także Piernikowa Aleja Gwiazd.
} 
zabytki były udostępniane szerszej publiczności na wystawach stałych dotyczących rzemiosła artystycznego jak i czasowych. W działalności Muzeum Okręgowego w Toruniu miała znaczenie praca kilku kolejnych pokoleń muzealników nad ochroną, opracowywaniem i udostępnianiem obiektów piernikarskich zarówno na wystawach stałych jak i czasowych w Toruniu oraz w kraju i za granicą a także realizacja działalności edukacyjnej. Jej uwieńczeniem było powstanie stałej i mobilnej wystawy „Świat toruńskiego piernika”, powołanie Działu Historii Toruńskiego Piernikarstwa i otwarcie w 2015 r. Muzeum Toruńskiego Piernika ${ }^{62}$.

Aktualną i istotną kwestią staje się ochrona dziedzictwa niematerialnego związanego z toruńskim piernikarstwem. W ostatnich latach prowadzono badania i dyskusję nad możliwością zarejestrowania wypieku toruńskich pierników na krajowej liście dziedzictwa niematerialnego. Warto wspomnieć tutaj przykład chorwackich pierników - licitarów, które dzięki m.in. współpracy między piernikarzami a muzealnikami zgłoszono i zarejestrowano na Liście Niematerialnego Dziedzictwa UNESCO [Biškupić Bašić 2000]. Analiza pokazała, że taka rejestracja w przypadku toruńskich pierników byłaby trudna do przeprowadzenia, m.in. ze względu na to, że obecnie wytwarzane są one w sposób przemysłowy, w jednej fabryce, według określonych receptur dostępnych bardzo wąskiemu gronu osób. Nie umniejsza to roli najstarszej firmy cukierniczej w Polsce, założonej w 1763 r. w przechowywaniu i przekazywaniu wiedzy na temat sposobów wytwarzania pierników przez kolejne pokolenia piernikarzy. W Fabryce Cukierniczej „Kopernik” SA zgromadzono obiekty historyczne (dokumenty, maszyny, narzędzia, zdjęcia, opakowania), które systematycznie przekazywano oraz przekazuje się nadal do muzeum. Prowadzone jest archiwum m.in. opakowań oraz dokumentacja fotograficzna i filmowa etapów produkcji. Oprócz obecnie przechowywanych drewnianych zabytkowych form, pochodzących jeszcze z pocz. XX w., tworzone były i są nadal kolejne

\footnotetext{
${ }^{62}$ Informacje o powstaniu i kształtowaniu toruńskiej muzealnej kolekcji omawia szerzej wydana w lipcu 2020 roku publikacja „Formy piernikarskie ze zbiorów Muzeum Okręgowego w Toruniu” autorstwa Małgorzaty Mikulskiej-Wernerowicz i Krzysztofa Lewandowskiego, pracowników Działu Historii Toruńskiego Piernikarstwa, która stanowi część zadania pt.: „Od katalogu do wystawy o formach piernikarskich z Muzeum Okręgowego w Toruniu. Badania Toruńskiego Piernikarstwa”. Dwuletni projekt dofinansowano ze środków Ministra Kultury i Dziedzictwa Narodowego pochodzących z Funduszu Promocji Kultury. https:// muzeum.torun.pl/blog/formy-piernikarskie-ze-zbiorow-muzeum-okregowego-w-toruniu/ data odczytu:15.11.2020.
} 
drewniane oraz metalowe formy do wypieku pierników figuralnych ${ }^{63}$. Sama produkcja tych ozdobnych pierników odbywa się, na etapie kształtowania, ręcznie. Pracownik sam wygniata zarobione wcześniej w maszynie ciasto i odciska wybrany kształt, po czym własnoręcznie go wycina. Istnieją wśród pracowników wspomnienia i anegdoty, w których przekazywano, że sprawdzianem umiejętności piernikarza, było udane wytłoczenie piernika z największych, przechowywanych w fabryce form. Pierniki figuralne tworzą stały asortyment pamiątkarski w sklepach firmowych. W archiwalnych nagraniach z Polskich Kronik Filmowych pracownicy fabryki do kształtowania pierników figuralnych używają oryginalnych, zabytkowych form, przekazanych z biegiem czasu do muzeum ${ }^{64}$. Pomimo procesu umuzealnienia artefaktu, kształt został wiernie przeniesiony na matrycę mosiężną w latach 60. XX w. i do dzisiaj jest z powodzeniem używany ${ }^{65}$. W ostatnich latach fabryka realizując projekt: „Z serca fabryki”, odwołuje się do swojej historii, nagrywając i udostępniając m.in. wywiady z mistrzami piernikarskimi”66.

W szerszym kontekście zaangażowania mieszkańców miasta — lokalnej społeczności Torunia - w podtrzymywanie i kontynuowanie tradycji

${ }^{63}$ Ich twórcami byli i są m.in.: Andrzej Pietrzak, Zygmunt Kędzierski, Tadeusz Makowski (który zajmował się także naprawą form w fabryce).

${ }^{64}$ „Pierniki toruńskie” Polska Kronika Filmowa 52/49. Data wydania 21.12.1949 r., lektor: Andrzej Łapicki, numer tematu: 4 od 6:28-7:30, Widoczny proces kształtowania pierników figuralnych $\mathrm{z}$ dawnych form, obecnie znajdujących się $\mathrm{w}$ muzeum; http://www.repozy torium.fn.org.pl/?q=pl/node/5063; „Reportaż z toruńskiej fabryki pierników” Polska Kronika Filmowa 37/45 Data wydania: 22.12.1945, Czas trwania: 00:24, lektor: Władysław Hańcza, proces wypieku katarzynek http://www.repozytorium.fn.org.pl/?q=pl/node/4609. W Polskiej Kronice Filmowej z 1958 r. nr 15b/58, w reportażu „Toruńskie pierniki” również możemy zobaczyć zabytkowe formy w produkcji pierników figuralnych.

${ }^{65} \mathrm{~W}$ fabryce jest specjalny magazyn form służących do tego celu. W $1961 \mathrm{r}$. Dyrektor Michał Samulski przekazał oryginalne formy z Fabryki do Muzeum. W zamian Muzeum przekazało kopie z mosiądzu, które służyły do wytwarzania pierników figuralnych. Z biegiem czasu obok form mosiężnych zamówiono aluminiowe. Dziękuję Panu Przemysławowi Myśliwy - Prezesowi, Dyrekcji (Paniom Zdzisławie Olszewskiej i Annie Kowalskiej) oraz Pracownikom Fabryki, za możliwość przeprowadzenia kwerendy i udzielone informacje.

${ }^{66}$ Powstał cykl z filmami z doświadczonymi pracownikami fabryki m.in. z Pawłem Laskowskim - mistrzem piernikarskim pracującym od 1984 r. w Fabryce Cukierniczej „Kopernik” S.A. https://www.youtube.com/watch?v=t_xjLNyCXek, data odczytu: 03.06.2020, Witoldem Olszewskim — piekarz, https://www.youtube.com/watch?v=A6w4i09jybU, data odczytu: 03.06.2020. Marcinem Szczęsnym, Rafałem Przybyłowskim. Część z nich pobierała nauki jeszcze u mistrza Tadeusza Szymańskiego, który często brał udział w wyjazdach promocyjnych z pokazem wypieku toruńskich pierników m.in. w Barcelonie, Rydze, Goeteborgu i Norrköping ( $w$ tym ostatnim szwedzkim mieście wraz z pracownikiem muzeum Barbarą Kukowicz-Wirowską przygotowana była wystawa dawnych form i pokaz pracy współczesnego piernikarza toruńskiego), https://torun.wyborcza.pl/torun/1,48723,1378554. html, data odczytu: 03.06.2020. 
piernikarskich warto byłoby wskazać na dwa aspekty związane z ochroną dziedzictwa niematerialnego poprzez jego rejestrację.

Pierwszym pomysłem na ochronę dziedzictwa niematerialnego byłaby rejestracja zwyczaju wręczania pierników - piernikowego „gościńca” jako pamiątki z wizyty w Toruniu. Udokumentowanie wręczanie pierników łączy się co najmniej z XVII wiekiem. Zachowane są informacje o obdarowywaniu ważnych gości, a także wysyłaniu pieników władcom jako podarunek. Wśród lokalnej społeczności jest nadal żywa praktyka nabywania pierników i wręczania ich przybyłym członkom rodziny lub znajomym. W literaturze funkcjonuje pojęcie „gościńca” czyli pamiątki piernika przywiezionego przez turystów z podróży do Torunia. Torunianie wyjeżdżając z miasta również zabierają ze sobą pierniki jako prezenty. Także władze miasta i regionu przekazują piernikowe podarunki w trakcie oficjalnych wizyt ${ }^{67}$.

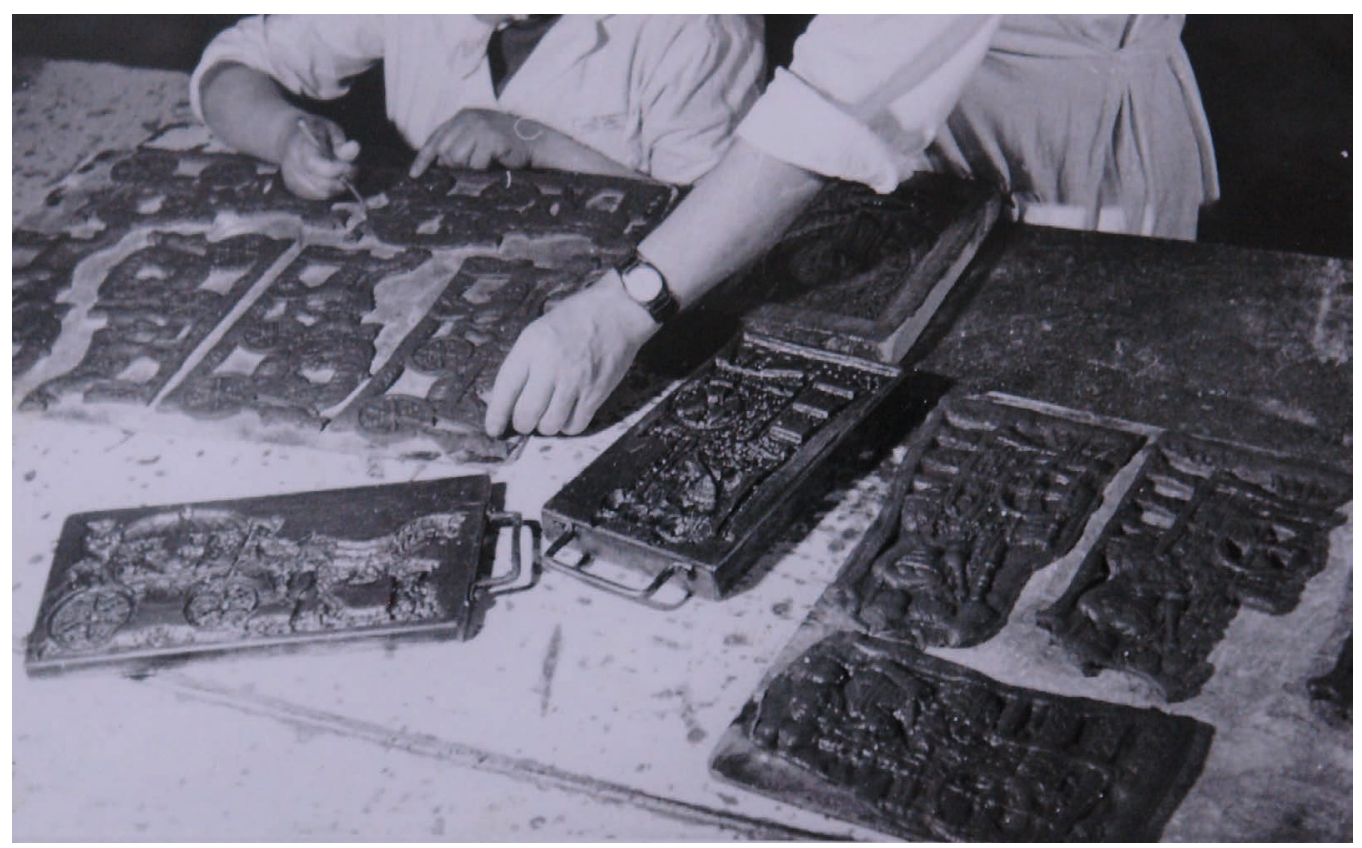

Il. 15. Wytwarzanie pierników figuralnych z mosiężnych i drewnianych form w toruńskiej fabryce, po 1960 roku, (Fot. Archiwum Fabryki Cukierniczej „Kopernik” SA)

\footnotetext{
${ }^{67} \mathrm{Na}$ ten temat m.in.: Kruszelnicka 1956: 16-17; W.W. [Wacław Wytyk?] O pierniku toruńskim wiadomości kilka. Specjał, którym Toruń królewskich gości witał, „Dzień Pomorza”, nr 296, 24-25-26.12.1937, s. 16; Jędrzejewska 2018a: s. 191-192. Słowo „gościniec” nie jest może obecnie rozpoznawalne, ale funkcja nabywania pierników w Toruniu jako prezent i pamiątka jest aktualna. [Woźniczko, Orłowski 2018: 112].
} 


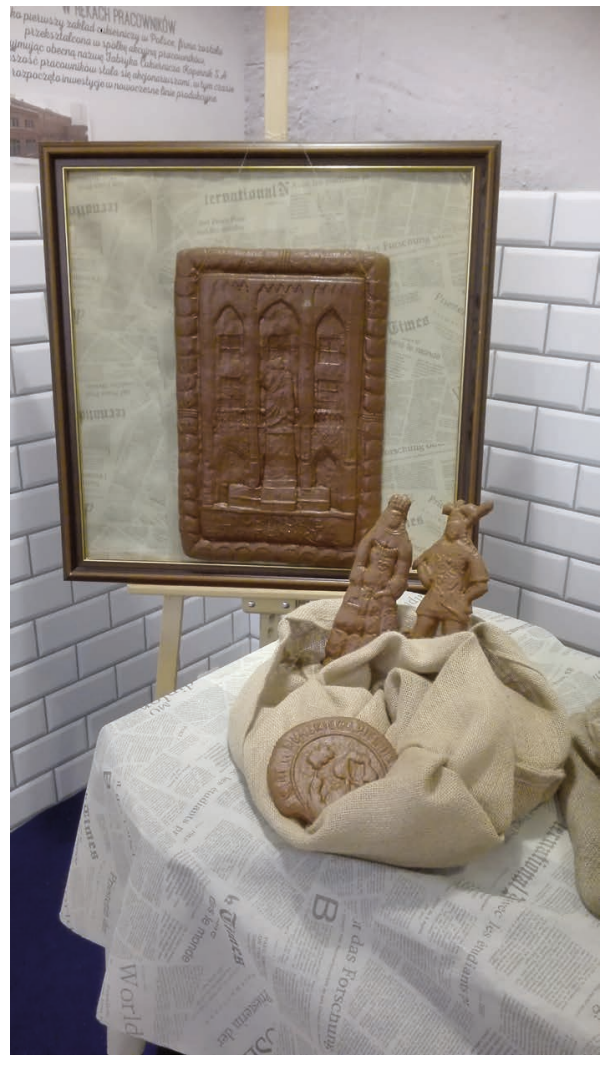

Il. 16. Toruńskie pierniki figuralne na wystawie w sklepie firmowym z okazji 255-lecia Fabryki Cukierniczej „Kopernik” SA. w Toruniu, sierpień 2018 rok, (Fot. Anna Kornelia Jędrzejewska)

Innym wariantem byłaby rejestracja zwyczajów związanych z kształtowaniem i wypiekaniem pierników figuralnych z Torunia. Proces ten udokumentować można, posługując się formami piernikarskimi, pochodzącymi z kolekcji warsztatów i firm piernikarskich gromadzonymi w Muzeum Okręgowym w Toruniu, od co najmniej XVII w.. Pomocne są tutaj zachowane opisy i źródła archiwalne oraz literackie. Pierniki figuralne wytwarza się nadal ręcznie w Fabryce Cukierniczej „Kopernik” SA. w oparciu o zabytkowe formy z XVII i XVIII w. Wypieki dekoracyjne powstają także współcześnie $\mathrm{w}$ toruńskich muzeach i piernikarniach ${ }^{68} \mathrm{w}$ ramach prowadzonych działań

\footnotetext{
${ }^{68}$ Żywe Muzeum Piernika, Toruńska Piernikarnia Mistrza Bogumiła, Starotoruńska Piernikarnia, Piernikarnia Forteczna, Piernikowa Przygoda. Drewniane formy piernikarskie można zakupić w sklepach muzealnych. Największy wybór form posiada sklep Emporium Toruń, prowadzony przez Dariusza Lipińskiego, [Jędrzejewska 2020]. Więcej o roli pierników w turystyce kulinarnej Torunia [Woźniczko, Orłowski 2018]. Działania edukacyjne w zakresie wypieku toruńskich pierników prowadzili także pracownicy toruńskich fabryk w okresie międzywojennym, artykuł: Fabrykacja ozdobnych pierników. Toruń nie zerwał z tradycja, w: Dzień Bydgoski, 1935, R.7, nr 292, s.7.
} 
edukacyjnych. Na potrzeby działalności tych warsztatów przygotowywane są nowe snycersko opracowane formy piernikarskie, zarówno inspirowane historią, jak i uwzględniające zapotrzebowanie na nowe współczesne wzory które przedstawiają np. architekturę i charakterystyczne elementy związane z Toruniem lub okazyjne wydarzenia, święta. Świadczy to o żywotności i zainteresowaniu, jakim cieszy się zwyczaj wypiekania pierników figuralnych w Toruniu. Współcześnie toruńskie pierniki figuralne, nie pełnią ze względu na skład ciasta (brak spulchniacza) funkcji konsumpcyjnych. Ich twardość powoduje obniżenie walorów smakowych i sprawia, że stają się trudno — o ile w ogóle — jadalne. Niemniej atrakcyjny wygląd, tak mocno związany z historią i stylistyką okresu baroku działa na wyobraźnię, budzi sentyment, tworzy więzi z dawną epoką.

\section{Podsumowanie}

Toruńskie pierniki figuralne zachowane w muzealnych kolekcjach w Polsce i na świecie oraz zabytkowe formy piernikarskie przechowywane w Muzeum Okręgowym w Toruniu i innych muzeach jak i w Fabryce Cukierniczej „Kopernik” SA świadczą o znaczeniu rzemiosła i przemysłu piernikarskiego dla Torunia oraz Polski a także utrwalają pozycję piernika toruńskiego wśród innych, charakterystycznych wyrobów piernikarskich w Europie ${ }^{69}$.

Kilkadziesiąt toruńskich pierników znajdujących się obecnie w omówionych muzealnych zbiorach powstało w dawnych fabrykach rodów Weese, Thomas oraz w Fabryce Cukierniczej „Kopernik” SA. Zaprezentowane wypieki wytłoczono w historycznych drewnianych formach, które częściowo przepadły podczas zawieruchy wojennej. Dzięki zachowanym wyciskom znamy wzory zaginionych klocków piernikarskich. Pierniki z nich ukształtowane są zatem cennym materialnym śladem dokumentującym wiedzę o wizerunkach utraconych form. Prawdopodobnie przygotowywano je z ciast zarabianych w tych nieistniejących dziś zakładach. W tym kontekście szczególnie ważna jest świadomość, że wypieki te, to nie tyko obiekty przenoszące informację o tym, jak wyglądały pierniki wypieczone z form, ale również artefakty zawierające wiedzę o składzie ciast używanych we wspomnianych firmach. Podobnie jest w przypadku wypieków powstałych w latach 60. XX w. i póź-

\footnotetext{
${ }^{69}$ Pierniki toruńskie i ich formy są wzmiankowane w opracowaniach dotyczących tradycji piernikarskich w Europie m.in.: Stegmann 1875/1990; Piroska 1964; Jürgen 1968; Kürth 1981; Hörandner 1982; Hinrichsen 2008; Hinrichsen 2009; Pechová 2014; Hipp Berlin 2015. Na trwałość produkcji historycznego piernika toruńskiego zwraca uwagę Piroska 1964.
} 
niejszych w obecnej Fabryce Cukierniczej „Kopernik”. Piernik wówczas powstały może przybliżyć wiedzę o ówczesnym składzie ciasta na wypieki tradycyjne, historyczne. Dbałość o zachowanie i bezpieczeństwo zbiorów w muzeach pozwoli kolejnym pokoleniom odkrywać i poznawać nieznane dzieje toruńskich pierników.

Pierniki figuralne przechowywane w muzeach są przykładem wybitnego toruńskiego rzemiosła i przemysłu piernikarskiego. Stanowiły element życia codziennego mieszkańców Torunia oraz charakterystyczną, rozpoznawalną dla osób przybywających do miasta, atrakcję, symbol. Z biegiem wydarzeń dziejowych pierniki wykorzystywano w napięciach o charakterze narodowym i propagandowym. W czasach zaborów podkreślano przywiązanie Torunia do tradycji Zakonu Niemieckiego, w okresie powrotu miasta do wolnej Polski pierniki stały się przykładem staropolskiej tradycji i łączności Torunia z Królestwem Polskim, symbolem polskiego rzemiosła artystycznego ${ }^{70}$. W trakcie II wojny światowej wykorzystano piernikarstwo do celów propagandowych wiążąc je z niemiecką, narodową tradycją [Kleśta-Nawrocka 2019:39-40]. Po 1945 r. uosabiały przemysł, w który zaangażowane były kolejne pokolenia torunian. Ówczesny system doprowadził do nacjonalizacji lub likwidacji prywatnych fabryk i zakładów, tak jak miało to miejsce w przypadku rodziny Ruchniewicz. Niemniej pomimo zawirowań dziejowych wiedza o produkcji pierników w Toruniu oraz zwyczaje z nimi związane nie tylko przetrwały, ale z sukcesem zostały rozwinięte. Współcześnie pierniki toruńskie są symbolem miasta, z którym lokalni mieszkańcy na co dzień mają możliwość obcować i z którym czują się związani, a dla gości i turystów są atrakcją oraz szansą na spotkania nie tylko z zabytkami, ale i żywą tradycją, poprzez doświadczenie wzięcia udziału w warsztatach przygotowania toruńskiego piernika figuralnego.

Na walory poznawcze płynące z artefaktów jakimi są formy piernikarskie, a tym samym także wykonane z nich zabytkowe piernikowe odciski, w omawianym lokalnym kontekście, zwraca uwagę przywoływany już Krzysztof M. Kowalski:

Formy piernikarskie świadczą o parametrach pierników i w tym skromnym zakresie można ustalić wielkość głównie toruńskich specjałów. Podstawowe znaczenie to bezprecedensowy chyba w dziejach

\footnotetext{
${ }^{70}$ Więcej na temat wątków patriotycznych związanych z piernikarstwem toruńskim: https://historiaposzukaj.pl/wiedza,historiomat,832,historiomat_pierniki_patriotyczne. html, data odczytu: 03.06.2020.
} 
społeczeństw dokument związków rzemiosła artystycznego z rzemiosłem spożywczym. Dzięki najwyższym osiągnięciom w obu dziedzinach doszło do niezwykłego wytworu — piernika, łączącego w sobie walory płaskorzeźby i artykułu spożywczego [Kowalski 1993: 107].

Opieka nad zachowanym dziedzictwem materialnym w postaci historycznych pierników figuralnych jest także ochroną dziedzictwa niematerialnego związanego z tradycją kształtowania tych wyrobów i ich funkcjonowania w życiu społecznym zarówno mieszkańców Torunia i regionu, jak i przybywających gości czy turystów. Tym bardziej pilna staje się potrzeba naukowego opracowania tego zagadnienia, które łączy w sobie nie tylko aspekt cenny dla lokalnej czy nawet narodowej społeczności, ale także niesie w sobie unikatowe i jedyne w swoim rodzaju, wartości w kontekście światowym.

\section{Bibliografia}

\section{Ambrożewicz Teresa}

1978: Pieczywo odpustowe (ozdobne pieczywo ludowe - cz. 2), „Polska Sztuka Ludowa”, t. 32, nr 2., s.81-90.

\section{Berendt Elżbieta}

2005: Formy piernikarskie, [w:] Sztuka drewna. Meblarstwo i snycerstwo ludowe na Dolnym Śląsku, red. E. Berendt, Wrocław: Muzeum Narodowe we Wrocławiu.

\section{Biškupić Bašić Iris}

2000: Licitarska umiejeća.Medičarstvoi svječarstwo- obrt višestoljetne tradicije. Gingerbread skills. Gingerbread and candle making — craft of the age-old traditions, Zagreb: Etnographic Museum Zagreb.

\section{Bobecka Paulina}

2012: Pierniki toruńskie w historii i podaniach lokalnych, „Rocznik Toruński”, t. 39.

\section{Chwalewik Edward}

1927: Zbiory polskie. Archiwa, biblioteki, gabinety, galerie, muzea i inne zbiory pamiatek przeszłości w ojczyźnie i na obczyźnie w porządku alfabetycznym według miejscowości ułożone, T. 2, s. 256 Warszawa, Kraków: Wydawnictwo J. Mortkowicza, Towarzystwo Wydawnicze w Warszawie https://polona.pl/item/zbiory-polskiekartoteka-uzupelnien-cz-2,NTk3NjExNA/2/\#info:metadata.

\section{Dąbrowski Stanisław}

1926: Dawne pierniki toruńskie, „Roczniki Towarzystwa Naukowego w Toruniu”, r. 33.

\section{Dąbrowski Stanisław}

1931: Historja różnych zwyczajów, odczytana z toruńskich form piernikowych, „Słowo Pomorskie”, r. 11, nr 297 — Dodatek Świąteczny.

\section{Dąbrowski Stanisław}

1935: Piernik toruński. Artystyczny żywot staropolskich łakoci, „As. Ilustrowany magazyn tygodniowy”, nr 21. 


\section{Dobrzycki Jerzy}

1925: Cenny nabytek Muzeum Etnograficznego na Wawelu, „Głos Narodu”, nr 78.

\section{Dumanowski Jarosław}

2010: Tatarskie ziele w cukrze, czyli staropolskie słodycze, Warszawa: Muzeum Pałac w Wilanowie.

\section{Dumanowski Jarosław}

2016: Świat piernika i jego stolica, w: Z Torunia, teksty miejscem zainspirowane, red. Anna Nadolska-Styczyńska, Toruń: Wydawnictwo Naukowe Uniwersytetu Mikołaja Kopernika s.177- 193.

\section{Fischer Christa}

2013: Stolze Reiter, schöne Damen...: die Bilderwelt der Gebäckmodel, Ulm: Thorbecke Jan Verlag.

\section{Hinrichsen Torkild}

2008: Im Knusperhaus. Lebkuchen aus Europa, Husum: Husum Druck- und Verlagsgesellschaft.

\section{Hinrichsen Torkild}

2009: Das Kuchenherz: Lebkuchen aus Deutschland, Husum: Husum Druck- und Verlagsgesellschaft.

\section{Hipp Hans}

2015: Das Lebkuchenbuch, Berlin: Insel Verlag.

\section{Hörandner Edith}

1982: Model. Geschnitzte Formen für Lebkuchen, Spekulatius und Sprigerle, München: Callwey Verlag.

\section{Hudzik Elżbieta}

2018: Witraże projektu Zdzisława Kulikowskiego w katedrze św. Mikołaja w Elblagu, Studia Elbląskie, t. XIX (2018).

\section{Jędrzejewska Anna Kornelia}

2012: Pomoce dydaktyczne w działalności edukacyjnej Muzeum Okręgowego w Toruniu, [w:] Edukacja muzealna w Polsce Sytuacja, kontekst, perspektywy rozwoju. Raport o stanie edukacji muzealnej w Polsce, red. M. Szeląg, Warszawa: Narodowy Instytut Muzealnictwa i Ochrony Zbiorów.

\section{Jędrzejewska Anna Kornelia}

2013: Mikołaj Kopernik, Toruńskie pierniki i Gotyk na dotyk - interaktywne formy edukacji historycznej w Muzeum Okręgowym w Toruniu, [w:] Historia w muzeum. Muzeum. Formy i środki prezentacji, red. Michał F. Woźniak, Tomasz F. de Rosset, Wojciech Ślusarczyk, Bydgoszcz : Muzeum Okręgowe im. Leona Wyczółkowskiego ; Warszawa : Narodowy Instytut Muzealnictwa i Ochrony Zbiorów.

\section{Jędrzejewska Anna Kornelia}

2018a: Piernik ijego rola w kulturze, [w:] Dom. Codzienność i święto. Ceremonie i tradycje rodzinne. Studia historyczno-antropologiczne., red. Bożena Popiołek, Agnieszka Chłosta-Sikorska, Marcin Gadocha, Kraków: Wydawnictwo Naukowe Uniwersytetu Pedagogicznego. 


\section{Jędrzejewska Anna Kornelia}

2018b: Zbiory form piernikarskich w Toruniu od XVII wieku do 1926 roku w świetle inwentarza Stanisława Dąbrowskiego, [w:] Muzeum a pamięć — forma, produkcja, miejsce, red. Tomasz F. de Rosset, Ewelina Bednarz Doiczmanowa, Aldona Tołysz, Warszawa: Narodowy Instytut Muzealnictwa i Ochrony Zbiorów.

\section{Jędrzejewska Anna Kornelia}

2020: Kolekcje dawnych klocków piernikarskich jako źródło nowatorskich form wystawienniczych I inspirujacych działań edukacyjnych, [w:] Edukacja w muzeach i instytucjach kultury - aktualnie, red. Marcin Szeląg, Poznań-Warszawa: Centrum Turystyki Kulturowej TRAKT — operator Bramy Poznania i Traktu Królewsko-Cesarskiego w Poznaniu oraz Muzeum Pałacu Króla Jana III w Wilanowie, wersja epub.

\section{Jürgen Hansen Hans}

1968: Kunstgeschichte des Backwerks. Geschichte und Entwicklung der Gebäckarten und ihrer Formen, Oldenburg, Hamburg: Stalling.

\section{Kleśta-Nawrocka Aleksandra}

2016: Kucharz doskonały. Historyczno-kulturowy fenomen kuchni staropolskiej, Toruń: Polskie Towarzystwo Historyczne.

\section{Kleśta-Nawrocka, Aleksandra,}

2019: Z serca fabryki 1939-1951. Historia Fabryki Cukierniczej „Kopernik” S.A. w źródłach, Toruń: Muzeum Okręgowe w Toruniu.

\section{Kluczwajd Katarzyna}

2002: Spojrzenie na „Rzut”. O wyposażeniu domu i wzornictwie $w$ toruńskim wydaniu, Toruń: Muzeum Okręgowe w Toruniu.

\section{Kowalski Krzysztof M.}

1993: Artefakty jako źródło poznania: studium z teorii nauki historycznej, Gdańsk: Wydawnictwo Uniwersytetu Gdańskiego.

\section{Kruszelnicka Janina}

1956: Pierniki toruńskie i inne, Toruń: Muzeum Okręgowe w Toruniu.

\section{Kujot Stanisław}

1884: Toruńskie pierniki, „Roczniki Towarzystwa Naukowego w Toruniu”, r. 3.

\section{Kukowicz-Wirowska Barbara, Jędrzejewska Anna Kornelia}

2014: Dawna Fabryka Gustava Weese jako miejsce prezentacji tradycji rzemiosła i przemystu piernikarskiego. Od wystawy do Muzeum Toruńskiego Piernika, [w:] Technika i nauka w muzeum. Muzeum. Formy i środki prezentacji, red. Michał F. Woźniak, Marcin Zdanowski, Bydgoszcz : Muzeum Okręgowe im. Leona Wyczółkowskiego; Warszawa : Narodowy Instytut Muzealnictwa i Ochrony Zbiorów.

\section{Kürth Herbert}

1981: Kunst der Model, Leipzig: Edition Leipzig

\section{Magalski Mateusz}

2014: „Pierny chleb” z Torunia - niedoceniane dziedzictwo?, „Rocznik Toruński”, t. 41.

\section{Marciniak Tadeusz}

1978: Dziwne misterium w piwnicach Ratusza, „Nowości”, nr 1-2, VII (wycinek archiwalny w dokumentacji MOT). 
Mierzejewska Aleksandra, Załuska Joanna red., Markowska Iwona oprac.kat.

2018: Okupowany Toruń w obiektywie Kurta Grimma. Niemiecka fotografia propagandowa ze zbiorów Muzeum Okręgowego w Toruniu, Toruń: Muzeum Okręgowe $\mathrm{w}$ Toruniu.

\section{Mikulska-Wernerowicz Małgorzata, Lewandowski Krzysztof}

2020: Formy piernikarskie ze zbiorów Muzeum Okręgowego w Toruniu, Toruń: Muzeum Okręgowe w Toruniu.

\section{Pechová Jarmila}

2014: Perníkářskéformyve sbírkách Etnografického ústavu Moravkého zemského muzea, Brno: Moravské zemské muzeum.

\section{Piroska Weiner,}

1964: Carved honeycake moulds, Budapest: Athenaeum Printing House.

\section{Rumińska Anna}

2020: Antropologia piernika. Compendium piperatologiczne, Slow Food Dolny Śląsk, wersja elektroniczna, (opracowanie bez ISBN).

\section{Stegmann Friedrich Hermann}

1875/1990: Der Pfefferkuchenbäcker und Lebküchler oder Anweisung alle Sorten feiner und ordinärer Pfeffer-und Honigkuchen zu fertigen. Nebst genauer Angabe des Verfahrens der berühmten Nürnberger, Thorner, Danziger und Braunschweiger Lebküchler-Zünfte; sowie der Herdtellung belibterfeiner Pfeffernüßchen, der feinen Zuckerkuchen, der Makronen, Elisen und Punschkuchen, des Marcipans und verschiedener Konfekte, Weimar 1875, reprint Leipzig 1990: Zentral Antiquariat der DDR.

\section{Szelągowska Grażyna}

2020: Pierniki odpustowe, w: Formy piernikarskie ze zbiorów Muzeum Okręgowego $w$ Toruniu red. Mikulska-Wernerowicz Małgorzata, Lewandowski Krzysztof, Toruń: Muzeum Okręgowe w Toruniu, s.42-47.

\section{Sudziński Ryszard, Samulski Michał}

1971: Dzieje przemysłu piernikarskiego w Toruniu, „Rocznik Toruński”, z. 6.

\section{Udziela Seweryn}

1925: Pierniki toruńskie, dodatek do „Ilustrowanego Kuriera Codziennego”, nr 266, 28 września.

\section{Udziela Seweryn}

1927: Pierniki w Polsce, „Rzeczy Piękne, Organ Muzeum Przemysłowego w Krakowie”, r. VI., nr 10-11.

\section{Ulanowski Witold}

1935: Ciasto św. Priski, „Arkady”, r. 1, nr 8.

\section{W.W. [Wacław Wytyk?]}

1937: O pierniku toruńskim wiadomości kilka. Specjał, którym Toruń królewskich gości witał, „Dzień Pomorza”, nr 296, 24-25-26 grudnia.

\section{Wargowski Mieczysław}

1927: Zbiory ludowe na Wawelu, „Przewodnik Katolicki”, r. XXXIII, nr 30. 


\section{Woźniczko Magdalena, Orłowski Dominik}

2017: Europejskie muzea produktów żywnościowych i ich znaczenie $w$ turystyce kulinarnej, ZNUV, 54 (3).

\section{Woźniczko Magdalena, Orłowski Dominik}

2018: Pierniki jako element potencjału turystyki kulinarnej Torunia, ZNUV, 60 (3).

\section{Wójcik Halina}

1966: Pierniki odpustowe w południowej Małopolsce, „Polska Sztuka Ludowa”, t. 20, z. 3-4.

\section{Załęska Halina}

1962: Dział Sztuki, (Sprawozdania działów muzeum w Toruniu za lata 1945-1961), „Rocznik Muzeum w Toruniu”, t. 1, z. 2.

\section{Żywirska Maria}

1957: Rzeźbione formy piernikarskie, „Polska Sztuka Ludowa”, t. 11, z. 2.

\section{Strony internetowe}

ABC profilaktyki konserwatorskiej w muzeum. SERIA WYDAWNICZA Narodowego Instytutu Muzealnictwa i Ochrony Zbiorów. Ochrona Zbiorów, zeszyt nr 10/2015

ABC profilaktyki konserwatorskiej w muzeum (wyd. 2), Praca zbiorowa NIMOZ, Warszawa 2015: https://nimoz.pl/files/publications/25/Konserwacja_ABC_ wydanie\%20pierwsze_ochrona\%20zbiorow.pdf, data odczytu: 03.06.2020.

Fabrykacja ozdobnych pierników. Toruń nie zerwał z tradycją, w: Dzień Bydgoski, 1935, R.7, nr 292, s.7 https://kpbc.umk.pl/dlibra/publication/189728/edition/191830/ content

\section{Fünfmandler}

https://www.lebkuchen-pirker.at/de/funfmandler, data odczytu: 03.05.2020.

\section{Gingerbread figure}

https://www.horniman.ac.uk/object/20.11.63/94, data odczytu: 03.06.2020.

\section{Historia}

http://www.pokojski.com.pl/index.php?p=1\&s=2, data odczytu: 03.06.2020.

\section{Muzeum Kultury i Sztuki Ludowej}

https://www.horniman.ac.uk/object/authority/agent-4519, data odczytu: 3.06.2020.

Official catalogue of the Polish Pavilion at World's Fair in New York,

Warsaw 1939, https://polona.pl/item/official-catalogue-of-the-polish-pavilion-at-the -world-s-fair-in-new-york-1939,NDYxMjI5NDM/249/\#info:search:Gingerbread, data odczytu: 12.07.2020.

Online Collections Database - Polish Museum of America- Gingerbread https://polishmuseum.pastperfectonline.com/search?utf8=\%E2\%9C\%93\&search_criteria=gingerbread\&searchButton=Search

Poland in the World of Tommorow the Polish Pavilion „New York World's Fair”, wn., 1939 https://polona.pl/item/poland-in-the-world-of-tomorrow-the-polish-pavilion-newyork-world-s-fair,NzUwMDExMzc/0/\#info:metadata, data odczytu: 12.07.2020. 


\section{Sweetmeat mould}

https://collections.museumoflondon.org.uk/online/object/37595.html, data odczytu: 03.06.20.

Toruń w Krainie Wikingów, Gazeta Wyborcza, Toruń, 18 marca 2003

https://torun.wyborcza.pl/torun/1,48723,1378554.html, data odczytu: 03.06.2020.

\section{Bronwen}

2013 Keeping Food in our Collections, 18 July, https://www.horniman.ac.uk/story/ keeping-food-in-our-collections/, data odczytu: 03.06.2020.

\section{Ewbank Anne}

2019 Why Museums Display Ancient Pastries and Beef Older Than Christ. People love food, even when it's behind a glass case. September 13, https://www.atlasobscura. com/articles/food-in-museums, data odczytu: 03.06.2020.

\section{Fic-Lazor Anna}

2015: Magazynowanie zbiorów muzealnych. Rekomendacje dla mniejszych muzeów [w:] ABC profilaktyki konserwatorskiej w muzeum (wyd. 2), Warszawa, https://nimoz. pl/files/publications/25/Konserwacja_ABC_wydanie\%20pierwsze_ochrona\%20 zbiorow.pdf, data odczytu: 03.06.2020.

\section{Franken Beth}

2012: Pieces of Poland in its 2nd capital https://www.polishmuseumofamerica.org/ pieces-of-poland-in-its-2nd-capital/, data odczytu: 03.06.2020.

\section{Gilman Julie, Van Damme Claire, Demeulenaer Bruno, Devlieghere Frank}

2011 MAP as a conservation method for contemporary art with foodstuffs: three case studies, „CeroArt”, 7, https://journals.openedition.org/ceroart/2207?lang=en, data odczytu: 03.06.2020.

\section{Harvey Megan, Davidson Cerys, O’Hara Coralie}

2016 Food as collection object, 22 AUG, https://www.aucklandmuseum.com/discover/ stories/blog/2016/food-as-collection-object, data odczytu: 03.06.2020.

\section{Jeberien Alexandra, Lindhorst Christian}

2003: Achtung Kunst- und Kulturgut. Ein Leitfaden zum Umgang mit Ausstellungsobjekten, http://www.cwaller.de/didaktik_teil4/2care_exponatleitfaden.pdf s.36, data odczytu: 03.06.2020.

\section{Jędrzejewska Anna Kornelia}

2018: Pierniki dla królów i Marszałka Piłsudskiego Tradycje patriotyczne $w$ historii toruńskiego piernikarstwa https://historiaposzukaj.pl/wiedza,historiomat,832,historiomat_pierniki_patriotyczne.html, data odczytu: 03.06.2020.

\section{Jędrzejewska Anna Kornelia}

2019: Śladami toruńskich pierników http://www.piernikarka.pl/index.php/2019/07/18/ sladami-torunskich-piernikow/, data odczytu: 03.06.2020.

\section{Jędrzejewska Anna Kornelia}

2020: Wiersz o malarzu pierników http://www.piernikarka.pl/index.php/2020/03/21/ wiersz-o-malarzu-piernikow/, data odczytu: 03.06.2020.

\section{Kastner Stephan}

Der Stuck —Ein Gebäck aus Berchtesgaden https://www.berchtesgadeninfo.de/de/ku ltur-brauchtum-alpen/kulinarisches/der-stuck.html, data odczytu: 04.05.2020. 


\section{Levy Jennifer}

2008 From Sharks to Sugar: Addressing Conservation Issues of Non-Traditional Contemporary Art Media, 12.06. https://www.incca.org/sites/default/files/field_attachments/levy_j._from_sharks_to_sugar.pdf/levy_j._from_sharks_to_sugar. pdf s.38, data odczytu: 16.06.2020.

\section{Mikulska-Wernerowicz Małgorzata}

O kolekcji form piernikarskich ze zbiorów Muzeum Okręgowego w Toruniu 2020: https://muzeum.torun.pl/blog/formy-piernikarskie-ze-zbiorow-muzeum-okregowe go-w-toruniu/, data odczytu:15.11.2020

\section{Pachla-Wojciechowska Karolina}

Pierniktoruński-„katarzynka”https://etnomuzeum.eu/zbiory/piernik-torunski-katarzyn ka, data odczytu: 3.06.2020

\section{Rumińska Anna}

2018: Kuchnia pachnąca piernikiem: Dolnośląski Piernik Figuralny Slow Food w Pałacu Kamieniec https://artecubo.pl/blog/kuchnia-pachnaca-piernikiem-slow/, data odczytu: 16.07.2020.

\section{Rumińska Anna}

2019: Artystyczny Warsztat Piernikarski Slow Foodna 726-lecie dolnośląskiego piernikarstwa http://slowfooddolnyslask.org/woj-dla-dzieci/artystyczny-warsztat-piernikarski-slowfood-na-726-lecie-dolnoslaskiego-piernikarstwa/, data odczytu: 3.06.2020

\section{Rumińska Anna}

2020: Pierniki. Dolny Śląsk. piperatas tortas. Świdnica http://slowfooddolnyslask.org/ produkty/pierniki/pierniki-dolny-slask-piperatas-tortas-swidnica/, data odczytu: 16.07.2020.

\section{Tomaszewska-Bolałek Magdalena}

2020: Polish table, Foundation for the Development of Cultural and Culinary Diplomacy 'Bunkatura' https://bunkatura.pl/the-polish-table/, data odczytu: 15.11.2020.

\section{Anna Kornelia Jędrzejewska}

\section{The pastry masterpieces. Toruń gingerbread in museum collections in Poland and abroad}

The article presents the idea of collecting historical, figurative Torun gingerbread in Poland and abroad. Torun gingerbread cookies, regarded as one of the symbols of the Polish culinary heritage, were collected to in museums and exposed on permanent as well as on temporary exhibitions. The oldest of those objects are about one hundred years old. Some of them were baked in wooden gingerbread molds, which vanished during WW II. Gingerbread cakes and cookies (made in that way) are the only material trace left of how those molds looked as well as what the composition of the dough was. Hard, almost inedible figurative pastries played a significant role in social communication. Gingerbread, as well as gingerbread molds, are examples of durability, vivacity, continuity of gingerbread craft and industry tradition, which dates back to the $14^{\text {th }}$ century. Their shapes were connected with specific functions they had: decorative elements, gifts, souvenirs. Toruń gingerbread-cookies and cakes are 
an important part of cultural heritage, not only locally but also worldwide. The paper also refers to the problem of collecting and preserving food objects in museums.

Keywords: gingerbread, collection, gingerbread craft, culinary heritage, gingerbread mold, local community, piperatology, Torun, food in museum 